Human Evolution

Elsevier Editorial System(tm) for Journal of

Manuscript Draft

Manuscript Number: HUMEV-E-17-00529R1

Title: Dietary traits of the ungulates from the HWK EE site at Olduvai Gorge (Tanzania): diachronic changes and seasonality

Article Type: SI: Oldowan-Acheulean

Keywords: Carbon and oxygen stable isotope; Tooth mesowear and microwear; Oldowan; Bed II Olduvai Gorge

Corresponding Author: Dr. Florent Rivals,

Corresponding Author's Institution: ICREA and Institut Català de Paleoecologia Humana i Evolució Social (IPHES)

First Author: Florent Rivals

Order of Authors: Florent Rivals; Kevin Uno, PhD; Faysal Bibi, PhD; Michael Pante, PhD; Jackson Njau, PhD; Ignacio de la Torre, PhD

Abstract: The Oldowan site HWK EE (Olduvai Gorge, Tanzania) has yielded a large fossil and stone tool assemblage at the transition from Lower to Middle Bed II, ca. 1.7 million years ago. Integrated tooth wear and stable isotope analyses were applied on the three most abundant ungulate taxa from HWK EE, namely Alcelaphini, cf. Antidorcas recki (Antilopini) and Equus oldowayensis (Equini) to infer dietary traits in each taxon. Some paleodietary changes were observed for cf. Antidorcas recki and Equus oldowayensis based on tooth wear at the transition from the Lemuta to the Lower Augitic Sands (LAS) interval within the HWK EE sequence. Stable carbon and oxygen isotope data show no significant changes in bulk diet or hydroclimate between the Lemuta and LAS intervals. The combined tooth wear and stable isotope data suggest similar paleoecological conditions across the two HWK EE intervals, but that differences in vegetation consumed among ungulates may have resulted in changes in dietary niches. Integrating tooth wear and stable isotope analyses permits the characterization of ungulate diets and habitats at HWK EE where C4 dominated and minor mixed C3-C4 habitats were present. Our results provide a better understanding of the paleoenvironmental conditions of the Lemuta and LAS intervals. The LAS assemblage was mostly accumulated during relatively dry periods at Olduvai Gorge when grasses were not as readily available and grazing animals may have been more nutritionally-stressed than during the formation of the Lemuta assemblage. This helps to contextualize variations in hominin and carnivore feeding behavior observed from the faunal assemblages produced during the two main occupations of the site. 


\section{Dietary traits of the ungulates from the HWK EE site at Olduvai Gorge (Tanzania): diachronic changes and seasonality}

Florent Rivals ${ }^{* a, b, c}$, Kevin T. Uno ${ }^{d}$, Faysal Bibi ${ }^{\mathrm{e}}$, Michael C. Pante ${ }^{\mathrm{f}}$, Jackson Njau ${ }^{\mathrm{g}}$, Ignacio de la Torre ${ }^{\mathrm{h}}$

(a) ICREA, Pg. Lluís Companys 23, 08010 Barcelona, Spain

(b) Institut Català de Paleoecologia Humana i Evolució Social (IPHES), Zona Educacional 4, Campus Sescelades URV (Edifici W3), 43007 Tarragona, Spain

(c) Area de Prehistoria, Universitat Rovira i Virgili (URV), Avinguda de Catalunya 35, 43002 Tarragona, Spain

(d) Division of Biology and Paleo Environment, Lamont-Doherty Earth Observatory of Columbia University, Palisades, New York, 10964, USA

(e) Museum für Naturkunde, Leibniz Institute for Evolution and Biodiversity Science, Invalidenstraße 43, D-10115 Berlin, Germany.

(f) Department of Anthropology, Colorado State University, 1787 Campus Delivery, Fort Collins, CO, 80523, U.S.A.

(g) Department of Geological Sciences, Indiana University, 1001 E Tenth Street, Bloomington, IN 47405, USA

(h) Institute of Archaeology, University College London, 31-34 Gordon Square, WC1H OPY London, United Kingdom

* Corresponding author: florent.rivals@icrea.cat 


\begin{abstract}
The Oldowan site HWK EE (Olduvai Gorge, Tanzania) has yielded a large fossil and stone tool assemblage at the transition from Lower to Middle Bed II, ca. 1.7 million years ago. Integrated tooth wear and stable isotope analyses were applied on the three most abundant ungulate taxa from HWK EE, namely Alcelaphini, cf. Antidorcas recki (Antilopini) and Equus oldowayensis (Equini) to infer dietary traits in each taxon. Some paleodietary changes were observed for cf. Antidorcas recki and Equus oldowayensis based on tooth wear at the transition from the Lemuta to the Lower Augitic Sands (LAS) interval within the HWK EE sequence. Stable carbon and oxygen isotope data show no significant changes in bulk diet or hydroclimate between the Lemuta and LAS intervals. The combined tooth wear and stable isotope data suggest similar paleoecological conditions across the two HWK EE intervals, but that differences in vegetation consumed among ungulates may have resulted in changes in dietary niches. Integrating tooth wear and stable isotope analyses permits the characterization of ungulate diets and habitats at HWK EE where $\mathrm{C}_{4}$ dominated and minor mixed $\mathrm{C}_{3}-\mathrm{C}_{4}$ habitats were present. Our results provide a better understanding of the paleoenvironmental conditions of the Lemuta and LAS intervals. The LAS assemblage was mostly accumulated during relatively dry periods at Olduvai Gorge when grasses were not as readily available and grazing animals may have been more nutritionallystressed than during the formation of the Lemuta assemblage. This helps to contextualize variations in hominin and carnivore feeding behavior observed from the faunal assemblages produced during the two main occupations of the site.
\end{abstract}

Keywords: Carbon and oxygen stable isotopes; Tooth mesowear and microwear; Oldowan; Bed II Olduvai Gorge. 


\section{Introduction}

Recent excavations at Henrietta Wilfrida Korongo East East (HWK EE) by the Olduvai Geochronology Archaeology Project (OGAP), combined with Mary Leakey's original unpublished collections, together yield a remarkable assemblage of stone tools and faunal remains that are critical for understanding hominin habitat and behavior during the late Oldowan to Acheulean technological transition (de la Torre et al, this volume; de la Torre and Mora, this volume; Pante et al., this volume, Pante and de la Torre, this volume). In that regard, reconstructing the dietary behavior of ungulates at HWK EE provides data on any paleoecological change associated with the transition at this site.

The objectives of this paper are (1) to detect dietary shifts between two main stratigraphic intervals preserved at the site, namely the Lemuta Member and the Lower Augitic Sandstone (LAS), (2) to characterize seasonal patterns in the dietary intake of the most common herbivores in these two stratigraphic intervals. To achieve the first objective, we analyzed the paleodiet, through tooth mesowear and microwear and stable isotope analysis of tooth enamel of the most abundant taxa at HWK EE: Alcelaphini, cf. Antidorcas recki and Equus oldowayensis. For the second objective, we assessed two aspects of seasonality. First, we examined variability in microwear within a population from a species or tribe to assess whether the fossil assemblage derives from a single event, or a seasonal or longer term accumulation. Second, we used intratooth stable isotope analyses to evaluate seasonal changes in diet and hydroclimate.

Although stable isotopes are widely used to study dietary changes in various areas in the Plio-Pleistocene of East Africa (e.g., Bibi et al., 2013; Cerling et al., 2015; Kingston and Harrison, 2007), tooth wear studies on ungulate communities are still scarce, whether for microwear or mesowear. Most work to date has focused on specific taxa in South Africa (Boisserie and Merceron, 2011; Franz-Odendaal et al., 2003; FranzOdendaal and Solounias, 2004; Kaiser and Franz-Odendaal, 2004; Merceron and Ungar, 2005; Peter et al., 2016; Schubert et al., 2006; Stynder, 2009; Stynder, 2011; Ungar et al., 2007) or Central Africa (Blondel et al., 2010).

The combination of three dietary proxies, namely microwear, mesowear, and stable isotopes, provides data on three different timescales within the lifetime of an animal. Tooth microwear reflects the diet of the last days or week of life (Grine, 1986), 
mesowear indicates the last weeks or months (Fortelius and Solounias, 2000), and carbon and oxygen isotopes in tooth enamel reflect an animal's diet over the period of tooth formation (Kohn and Cerling, 2002). Development of the permanent dentition in ungulates usually occurs during the first 1 to 5 years of life (e.g., Brown et al., 1960; Hoppe et al., 2004). Discrepancies resulting from the integration of these three dietary proxies are usually due to changes in diets across the different timescales recorded by each proxy (Ecker et al., 2013; Marín Leyva et al., 2013; Mayte et al., 2016; SánchezHernández et al., 2016). This is the first study to combine tooth wear (both mesowear and microwear) and stable isotope approaches to the archaeological record at Olduvai Gorge.

\section{Material and methods}

\subsection{Material}

The HWK EE archaeological site is located in the Junction Area of Olduvai Gorge, stratigraphically positioned in the transitional interval from Lower to Middle Bed II (de la Torre et al, this volume; Stanistreet et al, this volume), and is dated to circa 1.7 million years ago (McHenry et al., 2016; McHenry, this volume) (Fig. 1). Teeth analyzed in this paper include specimens from the Leakey assemblage (Pante and de la Torre, this volume) and from the new excavations at the HWK EE site (de la Torre et al, this volume).

Recent fieldwork at HWK EE has distinguished three main stratigraphic intervals, namely (from bottom up) Lemuta, Lower Augitic Sandstone (LAS) and Tuff IIB (see Figure 1). The Lemuta member, which contains fluvial and lacustrine sediments, is separated from the upper intervals by a significant disconformity (see details in Stanistreet et al, this volume), after which fluvial deposits dominate the sequence of LAS and the Tuff IIB interval. Site formation processes at HWK EE are complex and most of the archaeological units are interpreted as palimpsests comprised of multiple accumulation episodes, including human, carnivore, and abiotic agents (de la Torre et al, this volume).

In this study, we selected the taxa present both in the Lemuta and the LAS stratigraphic intervals with significant dental sample sizes for tooth wear analyses 
(Table 1), i.e. cf. Antidorcas recki $(\mathrm{N}=10)$, Alcelaphini $(\mathrm{N}=43)$ and Equus oldowayensis $(\mathrm{N}=13)$. Data on other ungulates present at HWK EE, which were also sampled for tooth wear analyses, are discussed by Uno et al. (this volume). Dietary traits of these three taxa are examined through tooth mesowear and microwear analyses. We also present stable carbon and oxygen isotope data from fossil teeth sampled from the Lemuta and LAS stratigraphic intervals. As with the tooth wear analyses, we focus on the same three abundant taxa (Alcelaphini, cf. Antidorcas recki, and Equus oldowayensis), but also present additional stable isotope data from a wide range of mammalian taxa that include Bovidae (additional tribes: Hippotragini, Reduncini, and Tragelaphini), Cercopithecidae, Deinotheriidae, Giraffidae, Hippopotamidae, Hyaenidae, Rhinocerotidae, and Suidae. The number of samples analyzed for each taxon in the Lemuta and the LAS intervals are given in Table 2.

\subsection{Tooth mesowear analysis}

Mesowear analysis, first introduced by Fortelius and Solounias (2000), is a method of categorizing the gross dental wear of ungulate molars by evaluating the relief and sharpness of cusp apices in ways that are correlated with the level of abrasiveness in a species' diet. Mesowear is scored macroscopically from the buccal side of upper molars, preferably the paracone of M2 (Fortelius and Solounias, 2000). A diet with low levels of abrasion (high attrition) maintains sharpened apices on the buccal cusps as the tooth wears. In contrast, high levels of abrasion, associated with a diet of siliceous grass, results in more rounded and blunted buccal cusp apices. Cusp sharpness is sensitive to ontogeny among young individuals (which have not yet developed substantial wear facets) and among dentally senescent individuals. However, for intermediate age groups, mesowear is found to be less sensitive to age and more strongly related to diet (Rivals et al., 2007). Unworn (and marginally worn) teeth, extremely worn teeth, and those with broken or damaged cusp apices, are omitted from mesowear analysis. In this study, the standardized method introduced by Mihlbachler et al. (2011) is employed. The method is based on seven cusp categories (numbered from 0 to 6), ranging in shape from high and sharp (stage 0 ) to completely blunt with no relief (stage 6). The average value of the mesowear data from a single sample of fossil dentitions corresponds to the 'mesowear score' or MWS (Mihlbachler et al., 2011). Dental mesowear analysis was 
conducted by a single experienced researcher (FR) to reduce inter-observer error, following the recommendations of Loffredo and DeSantis (2014).

\subsection{Tooth microwear analysis}

Microwear features of dental enamel were examined using a stereomicroscope on high-resolution epoxy casts of teeth following the cleaning, molding, casting, and examination protocol developed by Solounias and Semprebon (2002) and Semprebon et al. (2004). This low-magnification microwear technique has been questioned in relation to repeatability and inter-observer error (DeSantis et al., 2013; Mihlbachler et al., 2012). Such problems may arise when observers are not properly trained in the microwear method or when comparing data that were collected by different researchers. To avoid this problem, in the present study all the data were collected by a single experienced observer (FR).

The occlusal surface of each specimen was cleaned using acetone and then $96 \%$ alcohol. The surface was molded using high-resolution silicone (vinylpolysiloxane) and casts were created using clear epoxy resin. All casts were carefully screened under the stereomicroscope. Those with badly preserved enamel or taphonomic defects (features with unusual morphology and size, or fresh features made during the collecting process or during storage) were removed from the analysis, following King et al. (1999). Casts were observed under incident light with a Zeiss Stemi 2000C stereomicroscope at 35x magnification, using the refractive properties of the transparent cast to reveal microfeatures on the enamel. Microwear scars (i.e., elongated scratches and rounded pits) were quantified on the paracone of the upper teeth in a square area of $0.16 \mathrm{~mm}^{2}$ using an ocular reticule. We used the classification of Solounias and Semprebon (2002) and Semprebon et al. (2004) which basically distinguishes pits and scratches. Pits are microwear scars that are circular or sub-circular in outline and thus have approximately similar widths and lengths, while scratches are elongated microfeatures that are not merely longer than they are wide, but have straight, parallel sides. Using average scratch and pit data, it is possible to discriminate between the dietary categories of leaf browser (i.e., eating woody and non-woody dicotyledonous plants), grazer (i.e., eating grass), and mixed feeders.

Finally, following Rivals et al. (2015), two measurements of variability of scratch density, namely the standard deviation (SD) and the coefficient of variation (CV) are 
used to estimate the duration of the accumulation of the faunal assemblages. The integration of these two measurements of variability permits the classification of each case into one of the following three categories: [A] seasonal or shorter time windows, [B] longer than a season (i.e., two or more contiguous seasons), or [C] separated events that occurred in different non-contiguous seasons.

\subsection{Stable isotope analysis}

Stable carbon and oxygen isotope ratios of tooth enamel are determined by an animal's diet and body water, respectively, and can therefore be used to reconstruct herbivore diets, ecosystem vegetation, and local hydroclimate (e.g., Kingston and Harrison, 2007; Levin et al., 2006; Uno et al., 2011; Van der Merwe, 2013). Tooth enamel carbon isotopes ratios of large herbivores reflect the proportion of $\mathrm{C}_{3}$ to $\mathrm{C}_{4}$ vegetation in their diet during the time in which the tooth formed. Oxygen isotopes in enamel are primarily controlled by the isotope ratio of precipitation but also influenced by food water; plant water; evaporative processes in soils, plants, and water sources; and animal physiology (Kohn et al., 1996; Levin et al., 2006; Luz et al., 1984). The fidelity of stable isotopes in fossil enamel is well established. Enamel was shown be resistant to isotopic alteration over geologic timescales based on modelling studies (Wang and Cerling, 1994). The $\mathrm{C}_{3}$ dietary signal from the teeth of known browsers (i.e., Giraffa and Deinotheriium) and a $\mathrm{C}_{4}$ signal from known grazers (e.g., Equidae) from the same fossil site supports the preservation of the primary diet signal in carbon isotopes (Kingston, 2011). Evidence for the preservation of oxygen isotopes in fossil enamel comes from the consistently low values of hippo enamel relative to other taxa, which is a result of their semi-aquatic lifestyle (Bocherens et al., 1996).

Stable carbon and oxygen isotope ratios are reported as delta $(\delta)$ values relative to the Pee Dee Belemnite (PDB) standard using permil (\%) notation where

$$
\delta^{13} \mathrm{C}\left(\text { or } \delta^{18} \mathrm{O}\right)=\left(\mathrm{R}_{\text {sample }} / \mathrm{R}_{\text {standard }}-1\right) \times 1000
$$

and $\mathrm{R}_{\text {sample }}$ and $\mathrm{R}_{\text {standard }}$ are the ${ }^{13} \mathrm{C} /{ }^{12} \mathrm{C}\left({ }^{18} \mathrm{O} /{ }^{16} \mathrm{O}\right)$ ratios in the sample and in the standard, respectively, and the $\delta^{13} \mathrm{C}$ and $\delta^{18} \mathrm{O}$ values of PDB are defined as $0 \%$.

Today in eastern Africa nearly all woody vegetation uses the $\mathrm{C}_{3}$ photosynthetic pathway, or Calvin cycle, while nearly all low elevation $(<1500 \mathrm{~m})$ grasses, some sedges (e.g., Cyperus papyrus), and select shrubs (e.g., Amaranthaceae) use the $\mathrm{C}_{4}$ pathway, or Hatch-Slack cycle (Cerling and Harris, 1999; Livingstone and Clayton, 
1980; Tieszen et al., 1979; Young and Young, 1983). The carbon isotope ratio of $\mathrm{C}_{3}$ plants is on average around $-28 \%$ with an observed range of about -36 to $-23 \%$. The wide range in $\delta^{13} \mathrm{C}$ values in $\mathrm{C}_{3}$ plants is controlled by environmental conditions: more negative values are found in closed canopy forests whereas xeric conditions-common in lowland eastern Africa-lead to more positive values (e.g., -26 to $-23 \%$ ). $\mathrm{C}_{4}$ plants exhibit a narrower range of values, from about -14 to $-10 \%$ in eastern Africa (Cerling et al., 2003a).

We establish end-member $\delta^{13} \mathrm{C}$ values in tooth enamel $\left(\delta^{13} \mathrm{C}_{\text {enamel }}\right)$ for $\mathrm{C}_{3}$ and $\mathrm{C}_{4}$ diets using estimated atmospheric $\delta^{13} \mathrm{C}$ value of $-6.7 \%$ and published values for the enrichment in ${ }^{13} \mathrm{C}$ between diet and tooth enamel (+14.1\%o). A detailed description of the procedure is found in Uno et al. (this volume).

Using these values, we calculate $C_{3}$ and $C_{4}$ end member enamel values of -11.9 $\pm 4 \%$ and $+2.8 \pm 2 \%$, respectively, where uncertainty reflects the range of variability in the $\delta^{13} \mathrm{C}$ values of $\mathrm{C}_{3}$ and $\mathrm{C}_{4}$ vegetation in the region today. These end member values are applied to a mixing model to calculate the percentage of $\mathrm{C}_{4}$ vegetation in an animal's diet, where

$$
\% \mathrm{C}_{4}=\left(\delta^{13} \mathrm{C}_{\text {enamel }}-\delta^{13} \mathrm{C}_{\mathrm{C} 3}\right) /\left(\delta^{13} \mathrm{C}_{\mathrm{C} 4}-\delta^{13} \mathrm{C}_{\mathrm{C} 3}\right) \times 100
$$

and $\delta^{13} \mathrm{C}_{\text {enamel }}$ is the measured value in tooth enamel, and $\delta^{13} \mathrm{C}_{\mathrm{C} 3}$ and $\delta^{13} \mathrm{C}_{\mathrm{C} 4}$ are the end member values listed above. We propagate the uncertainty in both the dietary end member values ( \pm 4 and $\pm 2 \%$ ) and in the analytical procedure $( \pm 0.1 \%$ ), which results in uncertainties of 12 to $30 \%$. Uncertainties in $\% \mathrm{C}_{4}$ in diet are higher towards the $\mathrm{C}_{4}$ end of the continuum. We define $\mathrm{C}_{3}$-dominated diets as those with $\delta^{13} \mathrm{C}$ values of $\leq-8 \%$ o $\left(c a .<25 \% \mathrm{C}_{4}\right)$, mixed $\mathrm{C}_{3}-\mathrm{C}_{4}$ diets as having values from -8 to $-1 \%$ o (ca. 25-75 $\left.\% \mathrm{C}_{4}\right)$, and $\mathrm{C}_{4}$-dominated diets as those with $\delta^{13} \mathrm{C}$ values of $\geq-1 \%$ o $\left(c a .>75 \% \mathrm{C}_{4}\right)$.

We serially sampled a single Equus oldowayensis tooth from the Lemuta interval to evaluate seasonality of diet and hydroclimate. Although limited to a single sample, the intratooth isotope profile provides an important snapshot of diet and body water over $\sim 1$ to 3 years of time that the tooth formed (Hoppe et al., 2004). To ameliorate blurring of the isotope signal recorded in the tooth due to enamel maturation and sampling geometry, we apply the inverse model developed by Passey et al. (2005) to reconstruct the primary input signal. A comprehensive description of the sampling methods and 
inverse modeling are given in Uno et al. (this issue). The inverse modeling approach of Passey et al. (2005) assumes constant growth of the tooth, which we realize is likely not the case in determinant ungulate molars (Bendrey et al., 2015; Zazzo et al., 2012).

Detailed methods for tooth sampling (serial and bulk), enamel pretreatment, and analysis on an isotope ratio mass spectrometer (IRMS) are provided in Uno et al. (this volume). Briefly, 1 to $5 \mathrm{mg}$ of powdered enamel was pretreated with a weak oxidizer followed by buffered acetic acid, then $\sim 0.5 \mathrm{mg}$ of powder was analyzed on a dual inlet Thermo Delta V+ IRMS via acid hydrolysis on a Kiel IV $\left(70^{\circ} \mathrm{C}\right.$; 10 -minute reaction time).

\subsection{Statistics}

The chi-square test was used to test for differences in the prevervation of the microwear patterns between Lemuta and LAS intervals. ANOVA and Tukey's HSD test permitted to test for differences in numbers of pits and scratches among the three taxa from the Lemuta and LAS intervals. The Mann-Whitney U test (equivalent to the Wilcoxon test) was employed to compare carbon and oxygen isotope distributions between Lemuta and LAS intervals for all taxa, the three most abundant (Alcelaphini, cf. Antidorcas recki, and Equus oldowayensis), and just the Alcelaphini. For all test, significance level was set to $p=0.05$.

\section{Results}

\subsection{Tooth wear results}

All tooth mesowear and microwear data are given in Table S1.

\subsubsection{Preservation of tooth microwear}

The preservation of microwear on the enamel surface of ungulate teeth from HWK EE is very good. As reported from the taphonomic analysis (Pante et al., this volume; de la Torre et al., this volume), bone preservation is also generally very good and the majority of bones in both intervals do not exceed Behrensmeyer's (1978) weathering stage 1, suggesting rapid burial. Preservation of microwear patterns is slightly higher in the LAS assemblage ( $80 \%$ of the 55 teeth sampled) than in the Lemuta ( $72 \%$ of the 54 
teeth sampled), but a chi-square test $\left(p=0.34, X^{2}=0.91\right.$, d.f. $\left.=1\right)$ shows these differences to be insignificant.

\subsubsection{Diachronic changes from Lemuta to LAS stratigraphic intervals}

Mesowear scores (MWS), which register the dietary signal on a timescale of several weeks to months (Fortelius and Solounias, 2000), show a smaller range of values in Lemuta (from MWS = 2.62 for Alcelaphini to MWS = 3.66 for cf. Antidorcas recki) and a much broader range of values in LAS (from MWS $=1.5$ for cf. Antidorcas recki to MWS = 5 for Equus oldowayensis) (Fig. 2A). Moreover, in the Lemuta the values for E. oldowayensis and cf. Antidorcas recki are overlapping, suggesting diets with similar abrasive properties for the two taxa. Among the three taxa considered in this study, the temporal trends in the two intervals are different. Mesowear scores show opposite changes for the equid Equus oldowayensis and cf. Antidorcas recki (Fig. 2A). Equus oldowayensis, displays a grass-dominated mixed feeding dietary signal in the Lemuta and a grazing signal in the LAS stratigraphic interval. Mesowear values indicate increased abrasion towards the LAS interval. Cf. Antidorcas recki has mesowear scores similar to extant mixed feeders, but microwear values shift from grazing in the Lemuta to browsing in the LAS. Finally, the Alcelaphini plot among mixed feeders and show a stable mesowear signal throughout the two stratigraphic intervals.

Regarding tooth microwear, the actual numbers of microwear features, numbers of scratches (NS) and numbers of pits (NP), do not show significant variation between the two stratigraphic intervals, except for cf. Antidorcas recki (Fig. 2B-C). Cf. Antidorcas recki shows a significant decrease both in the numbers of scratches and pits from Lemuta to LAS (Table 3), corresponding to a decrease in the proportion of grass in the diet, as previously reported for the mesowear data. The differences reported for Equus oldowayensis and the Alcelaphini between the two stratigraphic intervals are not significant (Table 3).

The bivariate plot of average pits and scratches values show the intermediate position of the Alcelaphini and Equus oldowayensis between the extant leaf browser and grazer ecospaces (Fig. 3). There are no significant differences within these taxa when comparing Lemuta and LAS specimens (Table 3). In contrast, cf. Antidorcas recki shows significant differences both in the numbers of pits and scratches between the Lemuta and LAS intervals (Fig. 3, Table 3). Cf. Antidorcas recki from the LAS 
plots close to the leaf browser ecospace, while those from the Lemuta have a higher number of scratches. Moreover on Fig. 3, Lemuta cf. Antidorcas recki plots above the extant grazers due to a higher number of pits. In general, tooth microwear results for all taxa in the Lemuta suggest mixed feeding and grazing, while at LAS they suggest mixed feeding and browsing.

3.1.3. Variability in dietary signal and seasonality established from tooth wear The analysis of variability in the microwear signal through the coefficient of variation $(\mathrm{CV})$ and the standard deviation (SD) on the numbers of scratches is used here to characterize seasonality in the accumulation of the ungulate assemblages in Lemuta and LAS stratigraphic intervals (Table 1, Fig. 4). The combination of these two measurements of variation ( $\mathrm{CV}$ and $\mathrm{SD}$ ) was reported to discriminate seasonal events based on the duration of the accumulation (Rivals et al., 2015).

Unfortunately, the data on Alcelaphini are not conclusive, neither for the LAS nor for the Lemuta, because the two samples fall on the boundary between zones $[\mathrm{A}]$ and [B] (Fig. 4), i.e. in the area where the probability is too high to provide a significant differentiation between the two assemblages $(p>0.05)$. It is not possible to conclude if the accumulation of the Alcelaphini remains preserves a seasonal signal or not.

The samples of cf. Antidorcas recki from the LAS and the Lemuta plot in area [B] of the graph (Fig. 4). This area corresponds to long-term accumulation i.e., one or more events spanning more than a single season.

The samples of Equus oldowayensis from the Lemuta plot in area [A], corresponding to seasonal accumulation events, while the sample from the LAS falls on the boundary between zones (Fig. 4). For the LAS assemblage, it is not possible to conclude if the accumulation of Equus oldowayensis spans several seasons or occurs every time at the same season. For the Lemuta, the assemblage definitely corresponds to population(s) that died during short events (a single season or less) but occurring every time at the same season.

Equus oldowayensis and cf. Antidorcas recki plot in two different areas of the graph, independently of the stratigraphic context. Consequently, there is no specific pattern related to each stratigraphic interval. In these two intervals, the equids suggest an accumulation during a shorter time frame than cf. Antidorcas recki, probably related to differences in seasonal availability of the two species in the surroundings of the site. 


\subsection{Stable isotope results}

Tooth enamel analyzed from the Lemuta $(n=34)$ and the LAS $(n=24)$ intervals indicate the majority of large mammals had $\mathrm{C}_{4}$-dominated diets, with few exceptions. In Table 4, we provide summary statistics of the carbon and oxygen isotope data from all taxa from both intervals. All isotope data and calculated $\% \mathrm{C}_{4}$ values are given in Table S2. We use the median and the range of values to describe the sample populations because diets are derived from a non-normal (i.e., bimodal) distribution of $\mathrm{C}_{3}$ and $\mathrm{C}_{4}$ dietary resources. As such, we use a non-parametric statistical test to assess differences in the distributions between the Lemuta and the LAS intervals. Results from a MannWhitney $\mathrm{U}$ test illustrate no significant differences in $\delta^{13} \mathrm{C}(p$-value $=0.23)$ or $\delta^{18} \mathrm{O}(p$ value $=0.52)$ values of the two populations between the Lemuta and LAS intervals (Table 5). The $\delta^{13} \mathrm{C}$ and $\delta^{18} \mathrm{O}$ data for all taxa are plotted in Figure 5. Median $\delta^{13} \mathrm{C}$ values from the Lemuta and the LAS intervals are +1.1 and $+0.3 \%$, respectively, corresponding to diets that were comprised of 89 and $83 \% \mathrm{C}_{4}$ (Table 4). The range in $\delta^{13} \mathrm{C}$ values is smaller $(-8.9$ to $+3.3 \%$ ) in the Lemuta than in the LAS interval $(-12.8$ to $2.6 \%$ ) due to the presence of several browsers (Deinotheriidae and Giraffidae) in the latter interval. The median $\delta^{18} \mathrm{O}$ values from the Lemuta and LAS members are +0.0 and +0.9 , respectively. The $\delta^{18} \mathrm{O}$ range of values is larger for the Lemuta samples $(-3.8$ to $5.1 \%$ ) than for those from the LAS ( -2.0 to $4.0 \%$ ). The larger range in oxygen isotope values in the Lemuta may simply be an artifact of the larger sample size from that interval (34 vs. 24).

\subsubsection{Stable isotope results of Alcelaphini, cf. Antidorcas recki, and Equus} oldowayensis

Summary statistics from the three most abundant Lemuta and LAS taxa, the Alcelaphini, cf. Antidorcas recki, and Equus oldowayensis, are given in Table 6. The $\delta^{13} \mathrm{C}$ and $\delta^{18} \mathrm{O}$ data for these three taxa from both stratigraphic intervals are plotted together in Figure 6. The carbon isotope data suggest stable diets between intervals, although sample sizes are small, particularly for E. oldowayensis in the LAS (n = 2) and cf. Antidorcas recki ( $\mathrm{n}=3$ for both intervals). The median $\delta^{13} \mathrm{C}$ values of Alcelaphini in the Lemuta and LAS intervals are +1.8 and $+2.2 \%$, respectively. This is equivalent to 
diets of 94 and $96 \% \mathrm{C}_{4}$ vegetation, respectively, with a total range of 74 to $100 \% \mathrm{C}_{4}$. For the mixed feeding cf. Antidorcas recki, median Lemuta and LAS $\delta^{13} \mathrm{C}$ values are $-5.8 \%$ and $-4.3 \%$, corresponding to diets of $41 \%$ and $45 \% \mathrm{C}_{4}$ vegetation. Despite the limited sample size ( $\mathrm{n}=3$ from each interval), cf. Antidorcas recki displays a wide dietary range, spanning 20 to $99 \% \mathrm{C}_{4}$ across both intervals (Table 6). Equid $\delta^{13} \mathrm{C}$ values indicate $\mathrm{C}_{4}$-dominated diets. Median $\delta^{13} \mathrm{C}$ values from the Lemuta and the LAS equids are $+1.2 \%$ and $-1.4 \%$, corresponding to diets of $89 \%$ and $71 \% \mathrm{C}_{4}$ vegetation, respectively, with a total range of 74 to $99 \% \mathrm{C}_{4}$ (Table 6). A Mann-Whitney U test comparing all 29 samples from these 3 lineages shows no significant differences between $\delta^{13} \mathrm{C}$ or $\delta^{18} \mathrm{O}$ values from the Lemuta and LAS intervals (Table 5). A MannWhitney U test comparing just the Lemuta and LAS Alcelaphini values also shows no significant differences in either isotope distribution (Table 5). Antilopini and equid samples are too small to apply the test.

The $\delta^{18} \mathrm{O}$ values from the three most abundant taxa Alcelaphini, cf. Antidorcas recki, and E. oldowayensis exhibit no significant changes throughout the Lemuta and the LAS intervals (Figure 7). Median $\delta^{18} \mathrm{O}$ values for Lemuta and LAS Alcelaphini are nearly identical, whereas values for cf. Antidorcas recki decrease by $1.6 \%$ between the Lemuta and the LAS intervals (Table 6). In contrast, median E. oldowayensis $\delta^{18} \mathrm{O}$ values become enriched by $0.8 \%$.

\subsubsection{Equus oldowayensis intratooth stable isotope profile}

Results from the E. oldowayensis intratooth profile, both measured and modeled, are shown in Figure 5 and given in Table S3. The modeled $\delta^{13} \mathrm{C}$ values range from -2.3 to

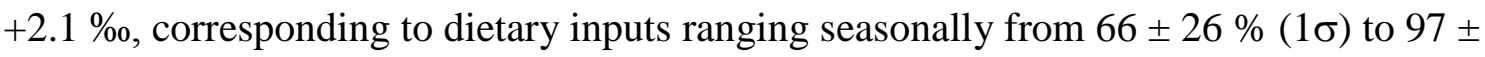
$19 \% \mathrm{C}_{4}$ (Table S3). Thus, the modeled data indicate that seasonally, the equid sampled had a $\mathrm{C}_{4}$-dominated to a mixed $\mathrm{C}_{3}-\mathrm{C}_{4}$ diet. Seasonal shifts are also evident in body water based on the range of modeled $\delta^{18} \mathrm{O}$ values $(-2.1$ to $+1.6 \%$ ).

\section{Discussion}

Food resources and habitats of three ungulate clades from the LAS and the Lemuta intervals at HWK EE were investigated through three independent proxies, carbon and 
oxygen stable isotopes, tooth mesowear, and tooth microwear. Reconstructed diets from the different proxies are summarized in Table 7.

\subsection{Food resources and habitats at HWK EE}

For the Antilopini, the $\delta^{13} \mathrm{C}$ values are suggestive of a range of browsing, mixed feeding, and grazing from the six individuals analyzed (three per interval), with a dietary range of 20 to $99 \% \mathrm{C}_{4}$ vegetation from both intervals (Table 3). These $\delta^{13} \mathrm{C}$ values are similar to those observed in the extant mixed-feeding antelope, Eudorcas thomsonii, whereas other extant species in eastern Africa, Nanger granti and Litocranius walleri, have mixed feeding to $\mathrm{C}_{3}$-dominated and $\mathrm{C}_{3}$-dominated diets, respectively (Cerling et al., 2003b; Van der Merwe, 2013). Thus, the limited number of isotope data from the Lemuta and the LAS intervals indicates a wide range of diets, similar to what is observed today in extant Antilopini. Tooth wear analyses also indicate a wide range of diets in the Antilopini, tending toward grazing in the Lemuta and toward browsing in the LAS. The tendency for a browsing mesowear signal in extant Antilopini is also reported by Louys et al. (2012), with low mesowear scores for all grazing Antilopini (i.e., values of 0 or 1). Tooth wear data suggest that individuals of cf. Antidorcas recki were seasonal mixed feeders but died at different seasons through the year, reflecting different diets at the time of death in the Lemuta and the LAS.

Carbon isotope data indicate that Alcelaphini had $\mathrm{C}_{4}$-dominated diets (range: 74 to $100 \%$, Table 6). Such high values of $\mathrm{C}_{4}$ vegetation for Alcelaphini both in the Lemuta and the LAS reflect a diet comprised of $\mathrm{C}_{4}$ grasses, similar to the hyper-grazing diet of extant Alcelaphini, Connochaetes taurinus and Alcelaphus buselaphus from northern Tanzania (Van der Merwe, 2013). In contrast to the stable isotope data, tooth mesowear and microwear patterns indicate mixed feeding traits both in the Lemuta and the LAS.

Equus oldowayensis carbon isotope values indicate a grazing diet predominantly composed of $\mathrm{C}_{4}$ plants (range: 77 to $95 \%$ ) both in the Lemuta and LAS. Tooth mesowear also indicates grazing, but microwear suggests mixed feeding at the time of death.

Various hypotheses could explain these discrepancies. First, these could be due to the fact that each proxy records diet on a different timescale (Davis and Pineda Munoz, 2016; Sánchez-Hernández et al., 2016). Stable isotopes of bulk enamel record a dietary 
average during tooth mineralization (usually the first years of an ungulate's life), while microwear reflects only the last days or weeks of life. A change in diet during the life of the individuals sampled, and especially during the last days or weeks will result in different dietary signals depending on the proxy analyzed. Consequently, the discrepancies observed are likely related to differences in the temporal scale of each proxy, tooth microwear being more sensitive to short term changes than the other two proxies (Davis and Pineda 2016).

An alternative hypothesis implicates the characteristics of the vegetation consumed, namely differences between the carbon isotopic composition $\left(\mathrm{C}_{3}\right.$ vs. $\left.\mathrm{C}_{4}\right)$ and the actual wear-inducing characteristics (e.g. phytolith content) of the plants themselves. For example, the low numbers of scratches reported here in taxa with enriched $\left(\mathrm{C}_{4}\right)$ isotopic values could be the result of feeding on $\mathrm{C}_{4}$ herbs, which have a low phytolith content (Baker et al., 1959). Several species from the paleobotanical record at Olduvai fit these characteristics. Bonnefille identified pollen from several $\mathrm{C}_{4}$ plants in the family Amaranthaceae (1984). This includes the herbaceous dicot Aerva javanica at VEK in Lower Bed II and the succulent Suaeda monoica at FLK in Bed I. Evidence of Cyperaceae include the $\mathrm{C}_{4}$ sedge Cyperus papyrus (Bamford, 2012; Bamford et al., 2006), though $\mathrm{C}_{3}$ sedges from wetland areas at FLK in Bed I have also been documented (Magill et al., 2016). Another possible non-grass dietary resource is wetland ferns, which Magill et al. (2016) suggest may have had carbon isotope ratios intermediate between $\mathrm{C}_{3}$ and $\mathrm{C}_{4}$ end member values. This suggestion is based on the $\delta^{13} \mathrm{C}$ values of $\mathrm{C} 30$ and $\mathrm{C} 32$ diols, which they assume were produced by ferns. In summary, there is evidence for several non-grass $\mathrm{C}_{4}$ plants, or plants with $\mathrm{CAM}$ or intermediate $\mathrm{C}_{3}-\mathrm{C}_{4}$ carbon isotope ratios, documented at Olduvai, particularly from Bed I. Most are associated with wetlands, paleolake Olduvai, or water courses. These plants may have been important resources for some herbivorous mammal species, but there is no evidence yet that they were widespread or were a significant contribution to the diets of large herbivores.

In the case of the discrepancy observed for Alcelaphini and Equus oldowayensis, where stable carbon isotopes indicate $\mathrm{C}_{4}$-dominated (i.e. grazing) diets, while microwear suggests a low abrasive diet (mixed feeding) comprised of plants with low phytolith content, one of these two hypotheses would explain the discrepancy. (1) A grazing diet during most of the life, and later a shift towards more browsing, at least in the last days of life. (2) The diets of these two ungulates included $\mathrm{C}_{4}$ dicots (possibly 
shrubs) that would impart a browsing signal in the tooth wear metrics and positive $\delta^{13} \mathrm{C}$ values associated with $\mathrm{C}_{4}$ vegetation.

Stable isotope analyses on the most abundant ungulates at HWK EE show no significant differences in carbon or oxygen isotope values between the Lemuta and Lower Augitic Sands (LAS) (Table 5 and Figure 5). Dietary behaviors are consistent throughout the sequence, with Alcelaphini and E. oldowayensis exhibiting $\mathrm{C}_{4-}$ dominated diets and cf. Antidorcas recki having a broad spectrum of diets. Regarding tooth wear analyses, in the Lemuta the three ungulate taxa analyzed are either grazers (Alcelaphini and Equus oldowayensis) or mixed feeders (cf. Antidorcas recki), while in the LAS ungulates are grazing (Equus oldowayensis), browsing (cf. Antidorcas recki) and mixed feeding (Alcelaphini). The diet of Equus oldowayensis appears to be stable, without substantial change throughout the sequence, although the intratooth isotope profile indicates seasonality of diet ranging from mixed $\mathrm{C}_{3}-\mathrm{C}_{4}$ to $\mathrm{C}_{4}$-dominated vegetation. For the bovids, the two taxa from the Lemuta show mixed feeding or grazing behavior, while those from the LAS show a tendency towards leaf browsing. However, the increase in leaf browsing is only significant for the cf. Antidorcas recki, as is supported both by mesowear and microwear. These changes are probably related to changes in resource availability (ecological or seasonal changes) like an increase in the availability of dicots. Interestingly, the Alcelaphini, which are usually the most mobile of the three taxa (Estes, 1991), have mesowear and microwear patterns that do not change from the Lemuta to the LAS. This may reflect the migratory behavior of Alcelaphini populations to access specific (and possibly similar) types of dietary resources through the year. The Lemuta interval, where the microwear pattern tends toward grazing, indicates that the alcelaphines would have been abundant at Olduvai during the wet season when grass would have been more available.

In the Lemuta interval, our results indicating grass consumption are supported by the data on phytoliths, which suggest the presence of areas with trees and $\mathrm{C}_{3}$ grasses, as well as open areas with $\mathrm{C}_{4}$ grasses (de la Torre et al., this volume). Nevertheless, tooth microwear does not permit us to differentiate a diet based on $\mathrm{C}_{3}$ or $\mathrm{C}_{4}$ grasses, however the phytoliths identified correspond mostly to $\mathrm{C}_{4}$ chloridoid grasses, which are very short grasses adapted to a dry and warm environment (R.M. Albert, personal communication). Microwear patterns with higher numbers of pits in the specimens from the Lemuta also indicate a dry environment due to the ingestion of grit and dust from 
the soil and/or exogenous dust on the leaves (Rivals and Semprebon, 2006; Semprebon and Rivals, 2007). In the LAS, the presence of $\mathrm{C}_{3}$ grass and the overall decline in grass phytoliths (i.e., from ca. 23 to $16 \%$ for the short cell rondel morphotype between the Lemuta and the LAS) would support this conclusion of more forested habitats than in the Lemuta (de la Torre et al., this volume). Moreover, the short cell saddle morphotype, associated with $\mathrm{C}_{4}$ grasses in the Poaceae subfamily, Chloridoideae, are present in the Lemuta sediments, but were not reported in the LAS sediments (de la Torre, this volume). Although the vegetation reconstruction from phytoliths indicates a larger fraction of woody vegetation (mostly palms) than is reflected in the overall dietary signal recorded by isotopes and mesowear, it is important to point out that the foraging areas and migratory ranges of large herbivores may stretch beyond the source area of the phytolith assemblage at HWK EE. In this scenario, the phytolith assemblage would reflect vegetation closely associated with littoral or fluvial margins whereas the diets of large mammals would reflect an integrated vegetation signal from a much larger area. This is in agreement with the fossil plant record from the eastern paleolake margin of Olduvai Gorge, where the paleovegetation included trees, shrubs, grasses, and sedges. The phytolith record also indicate the presence of palms (Albert et al., 2006, 2009; Bamford, 2012) and the pollen record indicates a diversity of dry and mesic trees, shrubs, and forbs (Bonnefille, 1984). The dearth of herbivores with $\mathrm{C}_{3}$-dominated diets (both in number of species and abundance) suggests a relatively smaller proportion of $\mathrm{C}_{3}$ vegetation on the landscape relative to $\mathrm{C}_{4}$ vegetation in the Lemuta and the LAS intervals.

\subsection{Variability in diets among ungulates and seasonality}

The multiproxy analysis of the Alcelaphini, cf. Antidorcas recki, and Equus oldowayensis in two stratigraphic intervals from HWK EE reveals differences in terms of dietary traits for the most abundant herbivores (as previously described in section 4.1). The lower range of mesowear values in the Lemuta compared to the LAS suggests diets based on types of plants of very different abrasiveness during the LAS interval. However, in the Lemuta there are significant differences in terms of pits and/or scratches among some taxa, while microwear values (scratches and pits) in the LAS are not significantly different for the three taxa (Table 2). Considering that microwear is more sensitive to seasonal variations than mesowear (Davis and Pineda 2016, Sánchez- 
Hernández et al. 2016), this opposite trend between the two units could suggest more marked seasonality in the Lemuta than in the LAS. Nonetheless, the palimpsest character of the deposits, which is particularly evident in the LAS (de la Torre et al, this volume), may also be contributing to mask potential seasonal episodes in the formation of the assemblage. In the single intratooth isotope profile on the Lemuta equid specimen, carbon isotopes indicate seasonal changes in diet (66 to $99 \% \mathrm{C}_{4}$ ), while the nearly $4 \%$ range in $\delta^{18} \mathrm{O}$ suggests relatively strong seasonality of precipitation (Figure 6). Based on the growth rates of equid teeth (Hoppe et al., 2004), the seasonal change in the $\delta^{18} \mathrm{O}$ value from the Lemuta equid tooth suggest a single annual rainy season.

In the Lemuta, Equus oldowayensis and Alcelaphini fed on similar resources, as indicated by similar isotopic and mesowear values. Nevertheless, even if they belong to the same dietary guild, these animals could eat different suites of grass species. In the LAS, mesowear shows clear differences in dietary traits, suggesting the three taxa were around the HWK EE site during the same season and exploited different vegetal resources.

As the ungulate community is habitat-dependent, the vegetation available must support the various ecological niches for the ungulates adapted to particular vegetal resources. Most of the ungulates from HWK EE are found to be mainly grazers or mixed-feeders (Equus oldowayensis and Alcelaphini), and few of them browsers or browse-dominated mixed feeders (cf. Antidorcas recki from the LAS). The latter were probably feeding on browse if resources available during the LAS time were limited. Alternately, browse was in low supply during Lemuta times, so A. recki may have been 'forced' to graze more then. Equus oldowayensis and Alcelaphini seem to occupy a grazing niche both in the Lemuta and the LAS, while cf. Antidorcas recki appears to shift its niche from grazing in the Lemuta to more browsing in the LAS. Alternately, as stated above, the Lemuta assemblage represents a shorter duration of accumulation time, such as a single season over many years, while the LAS represents a more varied seasonal signal over a longer duration. This would explain the higher variation of the wear data in $A$. recki in the LAS.

Both mesowear and microwear detect differences among species as well as diachronic changes through the HWK EE sequence. Trends reported for the two proxies are consistent in all taxa, i.e., values are shifting in the same direction both for mesowear and microwear (Figs. 2 and 3). However, depending on the taxa, the direction 
of these shifts, when significant, are different, i.e., shifting toward more grazing or more browsing.

For the Alcelaphini, both mesowear and microwear analyses yield consistent results. Tooth mesowear does not show significant change between the two stratigraphic intervals. The microwear pattern shows that Alcelaphini are classified among the extant mixed feeders, and indicate a slight increase in leaf browsing from the Lemuta to the LAS. However, in this case it is not possible to determine if they were seasonal mixedfeeders or not. The analysis of variability in the microwear pattern did not allow any conclusion about the seasonality for the Alcelaphini. Nevertheless, it was observed that the mesowear signal is stable and only microwear is changing. Considering that microwear is more sensitive to seasonality than mesowear (Davis and Pineda 2016, Sánchez-Hernández et al. 2016), it is probable that the difference is due to subtle variations in diet at the time of death.

For cf. Antidorcas recki, the trend observed with mesowear and microwear is the same reported for the Alcelaphini. However, the two methods are reporting highly significant differences in the results i.e., a significant increase in leaf browsing from the Lemuta to the LAS. As observed for the Alcelaphini, the microwear data are providing more extreme dietary habits than mesowear. As reported before, this discrepancy between mesowear and microwear should be linked to seasonal differences (SánchezHernández et al. 2016). Considering that the remains probably accumulated over a long timescale (certainly more than a single season), the results suggest the seasons of accumulation are different (or with a slight overlap) between the two stratigraphic intervals: seasons with diet based on grass in the Lemuta, and seasons with diet mainly based on browse in the LAS.

For the equid Equus oldowayensis, the mesowear trend is opposite to those previously reported for cf. Antidorcas recki and the Alcelaphini. Equus oldowayensis is characterized by an increase in the proportion of grass in the diet from the Lemuta to the LAS intervals. However, microwear patterns are not significantly different between the Lemuta and the LAS. Mesowear values clearly indicate grazing, but microwear values trend more toward mixed feeding. This difference could be related to a highly abrasive diet resulting from the presence of grit or dust on the plants, and/or to seasonality and food availability at the time of death. The results of the analysis of variability (Fig. 4), shows that the two samples plot close to each other (i.e. similar CV and SD values), and are located in the area corresponding to seasonal accumulations. Considering that 
changes in diet indicated by microwear from the Lemuta to the LAS are not significant, this suggests that the Equus oldowayensis assemblages correspond to the same season(s) in the two stratigraphic intervals.

Microwear variability indicate the existence of seasonal patterns in the formation of the Lemuta and the LAS assemblages. Considering the palimpsest nature of the deposits at HWK EE (de la Torre et al., this volume; Pante et al., this volume) our results would imply that accumulation of ungulates in the two intervals is following a seasonal pattern i.e., probably a succession of events at the same season(s) through the formation of each interval. Seasonality at HWK EE is also supported by the taphonomic analysis of fish assemblages which indicate variations in lake levels and the mass die-off during the dry season (Bibi et al., this volume). These seasonal fluctuations in lake levels certainly influenced the presence of ungulates in the habitats on the margins of the lake at Olduvai and resulted in the seasonal accumulations of their remains in both the Lemuta and the LAS intervals.

Increases in the browsing signature between the Lemuta and the LAS observed from microwear analyses of the bovids help to contextualize the variations in zooarchaeological data between the intervals (Pante et al., this volume). Higher tooth mark and percussion mark frequencies and lower limb bone epiphyseal:shaft fragment ratios observed for the Lemuta when compared with the LAS (Pante et al., this volume) suggest that carcasses acquired by hominins during the Lemuta interval were processed more extensively by both hominins and carnivores. The results for the LAS, which suggest that bone marrow may not have been exploited to its full potential during this interval, are consistent with carnivore consumption of nutritionally-stressed animals in the modern Serengeti ecosystem where carnivores were shown to incompletely ravage the fat- and grease-depleted bones of these carcasses resulting in lower tooth mark frequencies and more limb bone epiphyses relative to shaft fragments (Blumenschine and Marean, 1993). Together the feeding trace data, along with the microwear results that show a greater browsing component in the diets of the sampled bovids during the LAS, may indicate that the LAS assemblage was mostly accumulated during relatively dry periods at Olduvai when grasses were not as readily available and grazing animals may have been more nutritionally-stressed.

\section{Conclusions}


Tooth wear analyses on the most abundant ungulates from HWK EE reveal differences in dietary traits between the Lemuta and the LAS intervals likely corresponding to seasonal differences in the period of death of these animals in each stratigraphic interval. The lack of change in the distribution of carbon and oxygen isotope distributions between the Lemuta and the LAS indicate that there were not major dietary changes among herbivores or hydroclimatic change during this time. Furthermore, the carbon stable isotope data demonstrate that vegetation during Middle Bed II times was able to support the entire range of $\mathrm{C}_{3}$ to $\mathrm{C}_{4}$ diets, but that $\mathrm{C}_{4-}$ dominated diets were most prevalent among the large herbivores analyzed in this study.

The tooth wear results prove useful for disentangling the palimpsest character of the HWK EE assemblage, whose archaeo-stratigraphic architecture points to the existence of multiple accumulation events, which are generally jumbled together within successive archaeological units. As indicated by tooth wear analyses, these multiple accumulation events probably occurred seasonally, mostly during dry periods in the case of the LAS assemblage.

\section{Acknowledgements}

Fieldwork at HWK EE by OGAP was authorized by the Commission for Science and Technology, the Department of Antiquities, and the Ngorongoro Conservation Area Authority, Tanzania, and funded by the NSF (BCS-0852292) and the European Research Council-Starting Grants (283366). We are thankful to Merve Gumrukcu for her help in isotope sampling and Angeliki Theodoropoulou for her help in tooth wear sampling. Isotopic and tooth wear analyses were funded by the ERC-Starting Grants (283366), Columbia University's Center for Climate and Life (KTU) and the MINECO grants (HAR2013-48784-C3-1-P and HAR2016-76760-C3-1-P). FB was supported by the German Research Foundation (DFG, grant number BI 1879/1-1). Finally, we would

like to thank the three anonymous reviewers who provided valuable comments to improve this paper.

\section{References Cited}

Albert, R.M., Bamford, M.K., Cabanes, D., 2006. Taphonomy of phytoliths and macroplants in different soils from Olduvai Gorge (Tanzania) and the application to Plio-Pleistocene palaeoanthropological samples. Quaternary International 148, 78-94. 
Albert, R.M., Bamford, M.K., Cabanes, D., 2009. Palaeoecological significance of palms at Olduvai Gorge, Tanzania, based on phytolith remains. Quaternary International 193, 41-48.

Baker, G., Jones, L.H.P., Wardrop, I.D., 1959. Cause of wear in sheeps' teeth. Nature 184, 1583-1584.

Bamford, M.K., 2012. Fossil sedges, macroplants, and roots from Olduvai Gorge, Tanzania. Journal of Human Evolution 63, 351-363.

Bamford, M.K., Albert, R.M., Cabanes, D., 2006. Plio-Pleistocene macroplant fossil remains and phytoliths from Lowermost Bed II in the eastern palaeolake margin of Olduvai Gorge, Tanzania. Quaternary International 148, 95-112.

Behrensmeyer, A.K., 1978. Taphonomic and ecologic information from bone weathering. Paleobiology 4, 150-162.

Bendrey, R., Vella, D., Zazzo, A., Balasse, M., Lepetz, S., 2015. Exponentially decreasing tooth growth rate in horse teeth: implications for isotopic analyses. Archaeometry 57, 1104-1124.

Bibi, F., Souron, A., Bocherens, H., Uno, K., Boisserie, J.-R., 2013. Ecological change in the lower Omo Valley around 2.8 Ma. Biology Letters 9.Bibi, F., Pante, M., Souron, A., Stewart, K, Varela, S., Werdelin, L., Boisserie, J.R., Fortelius, M., Hlusko, L., Njau, J., de la Torre, I., Large Mammals and Fish from the Oldowan-Acheulean Transition at Olduvai Gorge, Tanzania, and the Paleoecology of the Serengeti. Journal of Human Evolution, this volume.

Blondel, C., Merceron, G., Likius, A., Mackaye, H.T., Vignaud, P., Brunet, M., 2010. Dental mesowear analysis of the late Miocene Bovidae from Toros-Menalla (Chad) and early hominid habitats in Central Africa. Palaeogeography, Palaeoclimatology, Palaeoecology 292, 184-191.

Blumenschine, R.J., Marean, C.W., 1993. A carnivore's view of archaeological bone assemblages, in: Hudson, J. (Ed.), From Bones to Behavior: Ethnoarchaeological and Experimental Contributions to the Interpretation of Faunal Remains. Carbondale: Center for Archaeological Investigations, University of Southern Illinois, pp. 273-300.

Bocherens, H., Koch, P., Mariotti, A., Geraads, D., Jaeger, J., 1996. Isotopic biogeochemistry (13 C, 18 O) of mammalian enamel from African Pleistocene hominid sites. Palaios 11, 306318.

Boisserie, J.-R., Merceron, G., 2011. Correlating the success of Hippopotaminae with the C4 grass expansion in Africa: Relationship and diet of early Pliocene hippopotamids from Langebaanweg, South Africa. Palaeogeography, Palaeoclimatology, Palaeoecology 308, 350361.

Bonnefille, R., 1984. Palynological research at Olduvai Gorge. National Geographic Society Research Reports 17, 227-243.

Brown, W., Christofferson, P., Massler, M., Weiss, M., 1960. Postnatal tooth development in cattle. American Journal of Veterinary Research 21, 7-34.

Cerling, T., Harris, J., 1999. Carbon isotope fractionation between diet and bioapatite in ungulate mammals and implications for ecological and paleoecological studies. Oecologia 120, 347-363.

Cerling, T., Harris, J., Leakey, M., Mudidia, N., 2003a. Stable isotope ecology of Northern Kenya, with emphasis on the Turkana Basin, in: Leakey, M.G., Harris, J.M. (Eds.), Lothagam: The Dawn of Humanity in Eastern Africa. Columbia University Press, New York, pp. 583-603. 
Cerling, T., Harris, J., Passey, B., 2003b. Diets of East African Bovidae based on stable isotope analysis. Journal of Mammalogy 84, 456-470.

Cerling, T.E., Andanje, S.A., Blumenthal, S.A., Brown, F.H., Chritz, K.L., Harris, J.M., Hart, J.A., Kirera, F.M., Kaleme, P., Leakey, L.N., Leakey, M.G., Levin, N.E., Manthi, F.K., Passey, B.H., Uno, K.T., 2015. Dietary changes of large herbivores in the Turkana Basin, Kenya from 4 to $1 \mathrm{Ma}$. Proceedings of the National Academy of Sciences 112, 11467-11472.

Davis, M., Pineda Munoz, S., 2016. The temporal scale of diet and dietary proxies. Ecology and Evolution 6, 1883-1897.

de la Torre, I., Mora, R., Oldowan technological behaviour at Olduvai Gorge, Tanzania: The HWK EE stone tool assemblage. Journal of Human Evolution, this volume.

de la Torre, I., Albert, R.M., Arroyo, A., Macphail, R., McHenry, L.J., Mora, R., Njau, J.K., Pante, M.C., Rivera-Rondón, C.A., Rodríguez-Cintas, A., Stanistreet, I.G., Stollhofen, H., Wehr, K., New excavations at the HWK EE site: archaeology, palaeoenvironment and site formation processes during late Oldowan times at Olduvai Gorge, Tanzania. Journal of Human Evolution, this volume.

DeSantis, L.R.G., Scott, J.R., Schubert, B.W., Donohue, S.L., McCray, B.M., Van Stolk, C.A., Winburn, A.A., Greshko, M.A., O'Hara, M.C., 2013. Direct comparisons of 2D and 3D dental microwear proxies in extant herbivorous and carnivorous mammals. PLoS ONE 8, e71428.

Ecker, M., Bocherens, H., Julien, M.-A., Rivals, F., Raynal, J.-P., Moncel, M.-H., 2013. Middle Pleistocene ecology and Neanderthal subsistence: Insights from stable isotope analyses in Payre (Ardèche, southeastern France). Journal of Human Evolution 65, 363-373.

Estes, R.D., 1991. The behavior guide to African mammals: including hoofed mammals, carnivores, primates. University of California Press, Berkeley.

Fortelius, M., Solounias, N., 2000. Functional characterization of ungulate molars using the abrasion-attrition wear gradient: a new method for reconstructing paleodiets. American Museum Novitates 3301, 1-36.

Franz-Odendaal, T.A., Kaiser, T.M., Bernor, R.L., 2003. Systematics and dietary evaluation of a fossil equid from South Africa. South African Journal of Science 99, 453-459.

Franz-Odendaal, T.A., Solounias, N., 2004. Comparative dietary evaluations of an extinct giraffid (Sivatherium hendeyi) (Mammalia, Giraffidae, Sivatheriinae) from Langebaanweg, South Africa (early Pliocene). Geodiversitas 26, 675-685.

Grine, F.E., 1986. Dental evidence for dietary differences in Australopithecus and Paranthropus: a quantitative analysis of permanent molar microwear. Journal of Human Evolution 15, 783-822.

Hoppe, K.A., Stover, S.M., Pascoe, J.R., Amundson, R., 2004. Tooth enamel biomineralization in extant horses: implications for isotopic microsampling. Palaeogeography, Palaeoclimatology, Palaeoecology 206, 355-365.

Jorayev, G., Wehr, K., Benito-Calvo, A., Njau, J., de la Torre, I., 2016. Imaging and photogrammetry models of Olduvai Gorge (Tanzania) by Unmanned Aerial Vehicles: A highresolution digital database for research and conservation of Early Stone Age sites. Journal of Archaeological Science 75, 40-56. 
Kaiser, T.M., Franz-Odendaal, T.A., 2004. A mixed-feeding Equus species from the Middle Pleistocene of South Africa. Quaternary Research 62, 316-323.

King, T., Andrews, P., Boz, B., 1999. Effect of taphonomic processes on dental microwear. American Journal of Physical Anthropology 108, 359-373.

Kingston, J.D., 2011. Stable isotopic analyses of Laetoli fossil herbivores, in: Harrison, T. (Ed.), Paleontology and geology of Laetoli: Human evolution in context. Springer, New York, pp. 293-328.

Kingston, J.D., Harrison, T., 2007. Isotopic dietary reconstructions of Pliocene herbivores at Laetoli: Implications for early hominin paleoecology. Palaeogeography, Palaeoclimatology, Palaeoecology 243, 272-306.

Kohn, M.J., Cerling, T.E., 2002. Stable isotope compositions of biological apatite. Reviews in Mineralogy and Geochemistry 48, 455-488.

Kohn, M.J., Schoeninger, M.J., Valley, J.W., 1996. Herbivore tooth oxygen isotope compositions: effects of diet and physiology. Geochimica et Cosmochimica Acta 60, 38893896.

Levin, N.E., Cerling, T.E., Passey, B.H., Harris, J.M., Ehleringer, J.R., 2006. A stable isotope aridity index for terrestrial environments. Proceedings of the National Academy of Sciences of the United States of America 93, 11201-11205.

Livingstone, D., Clayton, W., 1980. An altitudinal cline in tropical African grass floras and its paleoecological significance. Quaternary Research 13, 392-402.

Loffredo, L.F., DeSantis, L.R.G., 2014. Cautionary lessons from assessing dental mesowear observer variability and integrating paleoecological proxies of an extreme generalist Cormohipparion emsliei. Palaeogeography, Palaeoclimatology, Palaeoecology 395, 42-52.

Louys, J., Ditchfield, P., Meloro, C., Elton, S., Bishop, L.C., 2012. Stable isotopes provide independent support for the use of mesowear variables for inferring diets in African antelopes. Proceedings of the Royal Society B: Biological Sciences 279, 4441-4446.

Luz, B., Kolodny, Y., Horowitz, M., 1984. Fractionation of oxygen isotopes between mammalian bone-phosphate and environmental drinking water. Geochimica et Cosmochimica Acta 48, 1689-1693.

Magill, C.R., Ashley, G.M., Domínguez-Rodrigo, M., Freeman, K.H., 2016. Dietary options and behavior suggested by plant biomarker evidence in an early human habitat. Proceedings of the National Academy of Sciences, 201507055.

Marín Leyva, A.H., García Zepeda, M.L., Ponce Saavedra, J., Schaaf, P., Arroyo Cabrales, J., Alberdi, M.T., 2013. Inferencias de paleodietas en ungulados y proboscidios: limitaciones conceptuales y técnicas. Biológicas 15, 1-10.

Mayte, G.-B., García-Zepeda, M.L., López-García, R., Arroyo-Cabrales, J., Marín-Leyva, A.H., Meléndez-Herrera, E., Fuentes-Farías, A.L., 2016. Diet and habitat of Mammuthus columbi (Falconer, 1857) from two Late Pleistocene localities in central western Mexico. Quaternary International 406, Part B, 137-146.

McHenry, L.J., Njau, J.K., de la Torre, I., Pante, M.C., 2016. Geochemical "fingerprints" for Olduvai Gorge Bed II tuffs and implications for the Oldowan-Acheulean transition. Quaternary Research 85, 147-158. 
McHenry, L.J., Tephro-stratigraphy of Olduvai Bed II. Journal of Human Evolution, this volume.

Merceron, G., Ungar, P., 2005. Dental microwear and palaeoecology of bovids from the Early Pliocene of Langebaanweg, Western Cape province, South Africa. South African Journal of Science 101, 365-370.

Mihlbachler, M.C., Beatty, B.L., Caldera-Siu, A., Chan, D., Lee, R., 2012. Error rates and observer bias in dental microwear analysis using light microscopy. Palaeontologia Electronica $15,12 \mathrm{~A}, 22 \mathrm{p}$.

Mihlbachler, M.C., Rivals, F., Solounias, N., Semprebon, G.M., 2011. Dietary change and evolution of horses in North America. Science 331, 1178-1181.

Pante, M.C., de la Torre, I., A hidden treasure of the Lower Pleistocene at Olduvai Gorge, Tanzania: the Leakey HWK EE assemblage. Journal of Human Evolution, this volume.

Pante, M.C., Njau, J.K., Hensley-Marschand, B., Keevil, T.L., Martín-Ramos, C., Peters, R.F., de la Torre, I., The carnivorous feeding behavior of early Homo at HWK EE, Bed II, Olduvai Gorge, Tanzania. Journal of Human Evolution, this volume.

Passey, B.H., Cerling, T.E., Schuster, G.T., Robinson, T.F., Roeder, B.L., Krueger, S.K., 2005. Inverse methods for estimating primary input signals from time-averaged isotope profiles. Geochimica et Cosmochimica Acta 69, 4101-4116.

Peter, S.U., Jessica, R.S., Christine, M.S., 2016. Dental microwear differences between eastern and southern African fossil bovids and hominins. South African Journal of Science 112, 1-5.

Rivals, F., Mihlbachler, M.C., Solounias, N., 2007. Effect of ontogenetic-age distribution in fossil samples on the interpretation of ungulate paleodiets using the mesowear method. Journal of Vertebrate Paleontology 27, 763-767.

Rivals, F., Prignano, L., Semprebon, G.M., Lozano, S., 2015. A tool for determining duration of mortality events in archaeological assemblages using extant ungulate microwear. Scientific Reports 5, 17330.

Rivals, F., Semprebon, G., 2006. A comparison of the dietary habits of a large sample of the Pleistocene pronghorn Stockoceros onusrosagris from the Papago Springs Cave in Arizona to the modern Antilocapra americana. Journal of Vertebrate Paleontology 26, 495-500.

Sánchez-Hernández, C., Rivals, F., Blasco, R., Rosell, J., 2016. Tale of two timescales: Combining tooth wear methods with different temporal resolutions to detect seasonality of Palaeolithic hominin occupational patterns. Journal of Archaeological Science: Reports 6, 790797.

Schubert, B.W., Ungar, P.S., Sponheimer, M., Reed, K.E., 2006. Microwear evidence for PlioPleistocene bovid diets from Makapansgat Limeworks Cave, South Africa. Palaeogeography, Palaeoclimatology, Palaeoecology 241, 301-319.

Semprebon, G.M., Godfrey, L.R., Solounias, N., Sutherland, M.R., Jungers, W.L., 2004. Can low-magnification stereomicroscopy reveal diet? Journal of Human Evolution 47, 115-144.

Semprebon, G.M., Rivals, F., 2007. Was grass more prevalent in the pronghorn past? An assessment of the dietary adaptations of Miocene to recent Antilocapridae (Mammalia: Artiodactyla). Palaeogeography, Palaeoclimatology, Palaeoecology 253, 332-347. 
Solounias, N., Semprebon, G., 2002. Advances in the reconstruction of ungulate ecomorphology with application to early fossil equids. American Museum Novitates 3366, 149.

Stanistreet, I.G., McHenry, L.J., Stollhofen, H., de la Torre, I., Bed II Sequence Stratigraphic context of EF-HR and HWK EE archaeological sites, and the Oldowan/Acheulean succession at Olduvai Gorge, Tanzania. Journal of Human Evolution, this volume.

Stynder, D.D., 2009. The diets of ungulates from the hominid fossil-bearing site of Elandsfontein, Western Cape, South Africa. Quaternary Research 71, 62-70.

Stynder, D.D., 2011. Fossil bovid diets indicate a scarcity of grass in the Langebaanweg E Quarry (South Africa) late Miocene/early Pliocene environment. Paleobiology 37, 126-139.

Tieszen, L.L., Senyimba, M.M., Imbamba, S.K., Troughton, J.H., 1979. The distribution of C3 and $\mathrm{C} 4$ grasses and carbon isotope discrimination along an altitudinal and moisture gradient in Kenya. Oecologia 37, 337-350.

Ungar, P.S., Merceron, G., Scott, R.S., 2007. Dental microwear texture analysis of Varswater Bovids and Early Pliocene Paleoenvironments of Langebaanweg, Western Cape Province, South Africa. Journal of Mammalian Evolution 14, 163-181.

Uno, K.T., Cerling, T.E., Harris, J.M., Kunimatsu, Y., Leakey, M.G., Nakatsukasa, M., Nakaya, H., 2011. Late Miocene to Pliocene carbon isotope record of differential diet change among East African herbivores. Proceedings of the National Academy of Sciences 108, 6509-6514.

Uno, K., Rivals, F., Bibi, F., Pante, M., Njau, J., de la Torre, I., Large mammal diets and paleoecology across the Oldowan-Acheulean transition at Olduvai Gorge, Tanzania from stable isotope and tooth wear analyses. Journal of Human Evolution, this volume.

Van der Merwe, N.J., 2013. Isotopic ecology of fossil fauna from Olduvai Gorge at ca 1.8 Ma, compared with modern fauna. South African Journal of Science 109, 1-14.

Wang, Y., Cerling, T.E., 1994. A model of fossil tooth and bone diagenesis: implications for paleodiet reconstruction from stable isotopes. Palaeogeography, Palaeoclimatology, Palaeoecology 107, 281-289.

Young, H.J., Young, T.P., 1983. Local Distribution of $\mathrm{C}_{3}$ and $\mathrm{C}_{4}$ Grasses in Sites of Overlap on Mount Kenya. Oecologia 58, 373-377.

Zazzo, A., Bendrey, R., Vella, D., Moloney, A.P., Monahan, F.J., Schmidt, O., 2012. A refined sampling strategy for intra-tooth stable isotope analysis of mammalian enamel. Geochimica et Cosmochimica Acta 84, 1-13. 


\section{Figure captions}

Figure 1. A) Location of HWK EE in Olduvai Gorge [map template after Jorayev et al. (2016)]. B) Aerial view of HWK EE trenches. C) Correlation of HWK EE trenches, with the three main stratigraphic intervals (Lemuta, Lower Augitic Sandstone: LAS, and Tuff IIB Zone) and position of archaeological units (numbers in white boxes) (simplified from de la Torre et al, this volume, Figure 20).

Figure 2. Changes in dietary traits in equids and bovids between the Lemuta and Lower Augitic Sands (LAS) intervals indicated by (A) tooth mesowear scores (MWS) and the microwear variables: (B) number of scratches (NS) and (C) number of pits (NP).

Figure 3. Bivariate plot of the average numbers of pits and scratches in the fossil ungulates from HWK EE. Error bars correspond to the standard error of the mean ( \pm S.E.M.) for the fossil samples. Plain ellipses correspond to the Gaussian confidence ellipses $(p=0.95)$ on the centroid for the extant leaf browsers and grazers from Solounias and Semprebon (2002).

Figure 4. Bivariate plot of the standard deviation (SD) and coefficient of variation (CV) calculated on the numbers of scratches. Boundary lines between the three regions with the error probability (heat map) and the fossil samples from HWKEE. [A] = Seasonlong or shorter time windows, [B] Longer than a season, [C] Separated events that occurred in different non-contiguous seasons.

Figure 5. Carbon versus oxygen stable isotope ratios for all HWK EE taxa from (A) the Lower Augitic Sands (LAS; $n=24)$ and $(B)$ the Lemuta $(n=34)$ intervals. Most large herbivores from both intervals have $\mathrm{C}_{4}$-dominated diets $\left(>75 \% \mathrm{C}_{4}\right)$, with the exception of some Antilopini (cf. Antidorcus recki), Deinotheriidae, a Giraffa stillei, Hippopotamidae and Tragelaphini. A single Hyaenidae sample from the LAS interval likely had a diet that consisted of mostly grazing herbivores. [single column figure]

Figure 6. Carbon versus oxygen stable isotope ratios for Alcelaphini, Antilopini (cf. Antidorcus recki), and equids from the Lower Augitic Sands (LAS; filled symbols) and 
Lemuta (open symbols) intervals. The plot illustrates no significant changes occurred between intervals in the $\delta^{13} \mathrm{C}$ or $\delta^{18} \mathrm{O}$ values in the three lineages. [single column figure]

Figure 7. Intratooth stable isotope profile from an Equus oldowayensis lower first or second molar (L10-523) from the Lemuta interval. Time proceeds from right to left. The open circles and dashed line represent the measured isotope values. The solid line is the mean estimated input signal (shaded region is $\pm 2 \sigma$ uncertainty) from 100 inverse model results for A) $\delta^{13} \mathrm{C}$ and B) $\delta^{18} \mathrm{O}$ values. A) Modeled $\delta^{13} \mathrm{C}$ values indicate seasonal changes in diet $\left(-2.1\right.$ to $+2.3 \%$ ) ranging from a $\mathrm{C}_{4}$-dominated to pure- $\mathrm{C}_{4}$ diet over the period in which the tooth formed. B) The $\delta^{18} \mathrm{O}$ values range from -2.1 to $+1.6 \%$. The highest dietary input of $\mathrm{C}_{3}$ vegetation occurs from 45 to $25 \mathrm{~mm}$. This broadly corresponds to, but slightly precedes, the most enriched ${ }^{18} \mathrm{O}$ values (35 to $20 \mathrm{~mm}$ ). [single column figure] 
Table 1. Results from the tooth mesowear and microwear analyses from selected ungulates from HWK EE. Abbreviations: $\mathrm{N}$ = sample size; MWS = mesowear scores; $\mathrm{NP}=$ average number of pits; NS = average number of scratches; $\mathrm{SD}=$ standard deviation on NS; CV = coefficient of variation on NS; \%0-17 = percentage of individuals with 17 scratches or less (i.e. $\%$ of browsers in the sample).

\begin{tabular}{|c|c|c|c|c|c|c|c|c|}
\hline & & $\mathrm{Me}$ & owear & $\mathrm{Mi}$ & owear & & & \\
\hline & & $\mathrm{N}$ & MWS & $\mathrm{N}$ & NP & NS & SD & $\mathrm{CV}$ \\
\hline \multirow{2}{*}{ cf. Antidorcas recki } & LAS & 6 & 1.50 & 6 & 16.75 & 13.25 & 3.402 & 0.257 \\
\hline & Lemuta & 4 & 2.75 & 4 & 28.75 & 22.75 & 3.862 & 0.170 \\
\hline \multirow{2}{*}{ Alcelaphini } & LAS & 20 & 2.80 & 15 & 18.07 & 15.53 & 2.949 & 0.190 \\
\hline & Lemuta & 23 & 2.65 & 19 & 18.97 & 18.68 & 2.750 & 0.147 \\
\hline \multirow{2}{*}{ Equus oldowayensis } & LAS & 3 & 5.00 & 5 & 16.40 & 17.50 & 2.208 & 0.126 \\
\hline & Lemuta & 4 & 4.00 & 8 & 15.06 & 17.00 & 2.478 & 0.146 \\
\hline
\end{tabular}


Table 2. Number of teeth analyzed for carbon and oxygen isotope ratios by mammalian family. Bovidae are further specified to tribe. Stable isotope and tooth wear analyses data are both presented for taxa in bold italics.

\begin{tabular}{lrr}
\hline \multicolumn{1}{c}{ Family } & Lemuta & LAS \\
\hline Bovidae & 12 & 4 \\
$\quad$ Alcelaphini & 3 & 3 \\
Antilopini (cf. A. recki) & -- & 1 \\
Bovini & 2 & 2 \\
$\quad$ Hippotragini & 2 & 1 \\
Reduncini & 1 & 1 \\
$\quad$ Tragelaphini & 1 & -- \\
$\quad$ Indet. & 1 & -- \\
Cercopithecidae & -- & 2 \\
Deinotheriidae & 5 & 2 \\
Equidae & -- & 1 \\
Giraffidae (Giraffa) & 1 & 1 \\
Giraffidae (Sivatherium) & -- & 1 \\
Hyaenidae & 2 & -- \\
Hippopotamidae & 3 & 2 \\
Rhinocerotidae & 1 & 3 \\
Suidae & $\mathbf{3 4}$ & $\mathbf{2 5}$ \\
Total & &
\end{tabular}


Table 3. ANOVA and Tukey's HSD test results. Abbreviations: $\mathrm{df}=$ degrees of freedom; $\mathrm{SS}=$ sum of squares; $\mathrm{MS}=$ mean square; $\mathrm{An}=\mathrm{cf}$. Antidorcas recki; $\mathrm{Al}=$ Alcelaphini; $\mathrm{Eq}=$ Equus oldowayensis .

\section{Number of scratches (NS)}

ANOVA results:

$\begin{array}{lrcccc}\text { Source } & \text { df } & \text { SS } & \text { MS } & \text { F-ratio } & \text { p } \\ \text { Model } & 5 & 305.54 & 611.08 & 6.946 & 0.0398 \\ \text { Residual } & 57 & 501.45 & 87.97 & & \end{array}$

Pair-wise comparisons $-q$ values (Tukey's method); $p<0.05$ (significant comparisons are bold):

$$
\text { An LAS An Lem Al LAS Al Lem Eq LAS Eq Lem }
$$

An LAS

An Lemuta

\subsection{8}

Al LAS

2.131

6.736

Al Lemuta

4.985

3.882

2.854

Eq LAS

3.100

$\mathbf{5 . 7 6 7} 0.969$

1.885

Eq Lemuta

3.24

5.627

1.110

1.744

0.141

\section{Number of pits (NP)}

ANOVA results:

$\begin{array}{lrcccc}\text { Source } & \text { df } & \text { SS } & \text { MS } & \text { F-ratio } & \text { p } \\ \text { Model } & 5 & 551.09 & 110.22 & 3.756 & 0.0052 \\ \text { Residual } & 57 & 1672.46 & 293.41 & & \end{array}$

Pair-wise comparisons $-q$ values (Tukey's method); $p<0.05$ (significant comparisons are bold):

An LAS An Lem. Al LAS Al Lem. Eq LAS Eq Lem.

An LAS

An Lemuta

6.133

Al LAS

0.673

5.460

Al Lemuta

0.697

$\mathbf{5 . 4 3 6} 0.024$

Eq LAS

0.602

6.736

1.275

1.299

Eq Lemuta

0.412

$\mathbf{6 . 5 4 5} 1.085$

1.109

0.191 
Table 4. Summary statistics of carbon and oxygen stable isotope data for taxa from the Lemuta and LAS intervals at HWK EE.

\begin{tabular}{|c|c|c|c|c|c|c|c|c|c|c|c|c|}
\hline \multirow[b]{2}{*}{ Interval } & \multirow[b]{2}{*}{$\mathbf{N}$} & \multicolumn{3}{|c|}{$\% \mathrm{C4}$} & \multicolumn{4}{|c|}{$\delta^{13} \mathrm{C}(\%$, VPDB $)$} & \multicolumn{4}{|c|}{$\delta^{18} \mathrm{O}(\%, \mathrm{VPDB})$} \\
\hline & & mediar & $\min$ & $\max$ & median & $\max$ & $\min$ & range & median & $\max$ & $\min$ & range \\
\hline LAS & 24 & 83 & 0 & 99 & 0.3 & 2.6 & -12.8 & 15.5 & 0.9 & 4.0 & -2.0 & 6.0 \\
\hline Lemuta & 34 & 89 & 20 & 100 & 1.1 & 3.3 & -8.9 & 12.3 & 0.0 & 5.1 & -3.8 & 8.9 \\
\hline
\end{tabular}

Table 5. Mann-Whitney U test results comparing carbon and oxygen isotope distributions between Lemuta and LAS intervals for all taxa; Al, An, and Eq; and Alcelaphini. None of the distributions differ significantly between intervals $(p<0.05)$

\begin{tabular}{lccr} 
& All taxa & Al, An, Eq & Al \\
\hline Carbon p-value & 0.2291 & 0.7992 & 1 \\
Oxygen p-value & 0.5174 & 0.3171 & 0.8615 \\
N (Lemuta /LAS) & $34 / 24$ & $20 / 9$ & $12 / 4$
\end{tabular}

Table 6. Summary statistics of carbon and oxygen stable isotope data for the three most abundant taxa from the Lemuta and LAS intervals at HWK EE.

\begin{tabular}{|c|c|c|c|c|c|c|c|c|c|c|c|c|c|}
\hline \multirow[b]{2}{*}{ Taxon } & \multirow[b]{2}{*}{ Interval } & \multirow[b]{2}{*}{$\mathrm{N}$} & \multicolumn{3}{|c|}{$\% \mathrm{C} 4$} & \multicolumn{4}{|c|}{$\delta^{13} \mathrm{C}(\%, \mathrm{VPDB})$} & \multicolumn{4}{|c|}{$\delta^{18} \mathrm{O}(\%, \mathrm{VPDB})$} \\
\hline & & & median & $\min$ & $\max$ & median & $\max$ & $\min$ & range & median & $\max$ & $\min$ & range \\
\hline \multirow{2}{*}{ cf. A. recki } & LAS & 3 & 45 & 32 & 99 & -5.3 & 2.6 & -7.2 & 9.8 & 1.4 & 2.8 & 1.0 & 1.7 \\
\hline & Lemuta & 3 & 41 & 20 & 94 & -5.8 & 1.9 & -8.9 & 10.8 & 3.0 & 3.3 & 0.2 & 3.1 \\
\hline \multirow{2}{*}{ Alcelaphini } & LAS & 4 & 96 & 85 & 99 & 2.2 & 2.6 & 0.5 & 2.1 & 0.5 & 1.8 & $\begin{array}{r}-1 . \\
3\end{array}$ & 3.1 \\
\hline & Lemuta & 12 & 94 & 74 & 100 & 1.8 & 3.3 & -1.1 & 4.4 & 0.1 & 3.1 & $\begin{array}{r}-1 . \\
8\end{array}$ & 5.0 \\
\hline \multirow{2}{*}{$\begin{array}{l}\text { Equus } \\
\text { oldowayensis }\end{array}$} & LAS & 2 & - & 83 & 87 & -1.4 & 0.9 & 0.3 & 0.6 & \multirow{2}{*}{$\begin{array}{r}0.5 \\
-0 . \\
3\end{array}$} & 0.9 & \multirow{2}{*}{$\begin{array}{r}0.0 \\
-0 \\
8\end{array}$} & 0.9 \\
\hline & Lemuta & 5 & 89 & 74 & 95 & 1.2 & 2.1 & -1.1 & 3.1 & & 0.3 & & 1.1 \\
\hline
\end{tabular}


Table 7. Summary of the dietary traits interpreted from carbon stable isotopes and tooth wear at HWK EE. Abbreviations: B = Browser; G = Grazer; G-MF = Grass-dominated mixed feeder; $\mathrm{MF}=$ Mixed feeder.

\begin{tabular}{llccc} 
& & \multicolumn{3}{c}{ Dietary proxies } \\
\cline { 3 - 5 } & & Carbon & Tooth & Tooth \\
& & isotopes & mesowear & microwear \\
\hline \multirow{2}{*}{ cf. Antidorcas recki } & LAS & MF, G & B & B \\
& Lemuta & B, MF, G & G-MF & G \\
\hline \multirow{2}{*}{ Alcelaphini } & LAS & G & MF & MF \\
& Lemuta & G & MF & MF \\
\hline \multirow{2}{*}{ E. olduwayensis } & LAS & G & G & MF \\
& Lemuta & G & G-MF & MF \\
\hline
\end{tabular}


Click here to download high resolution image

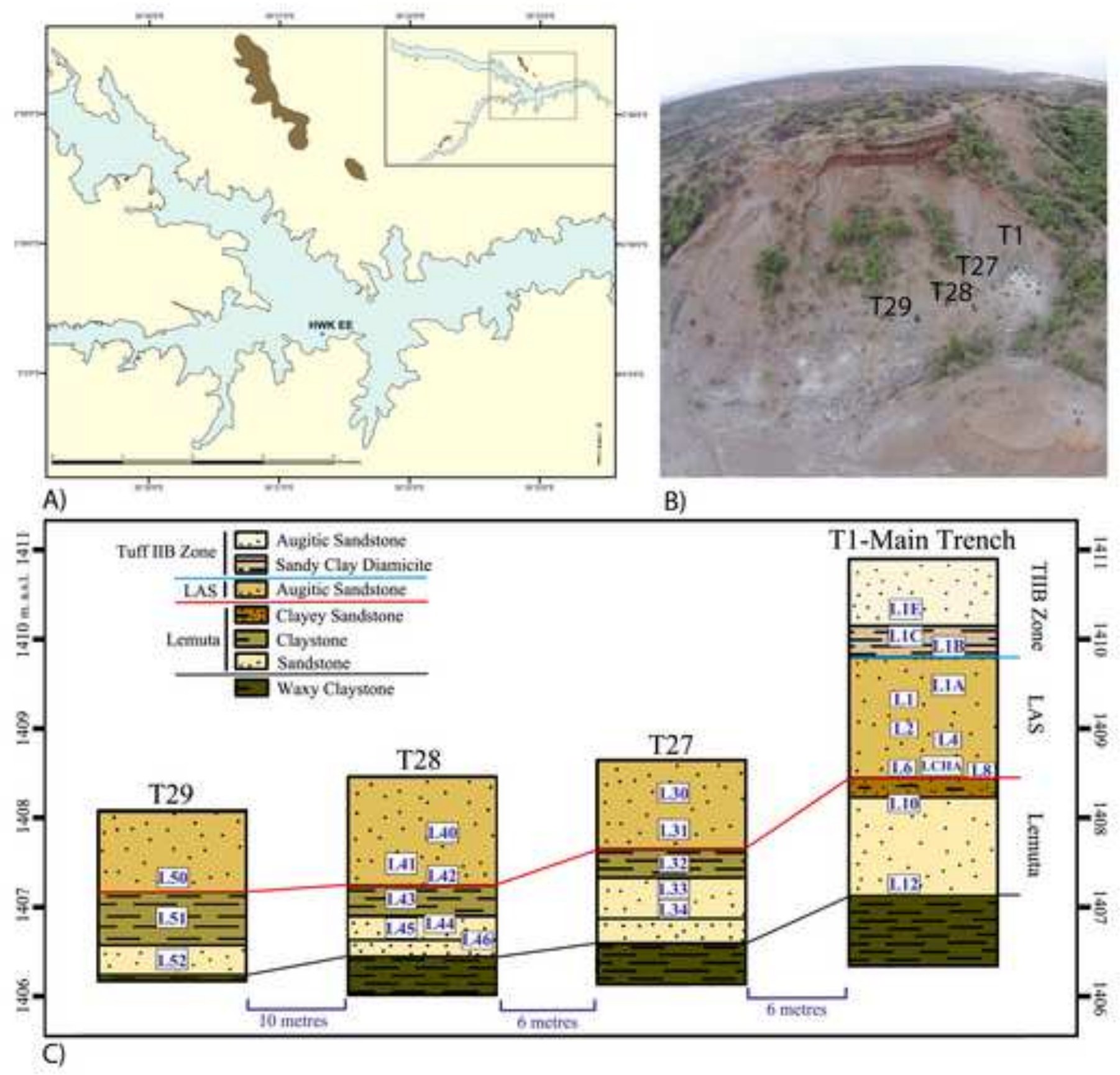




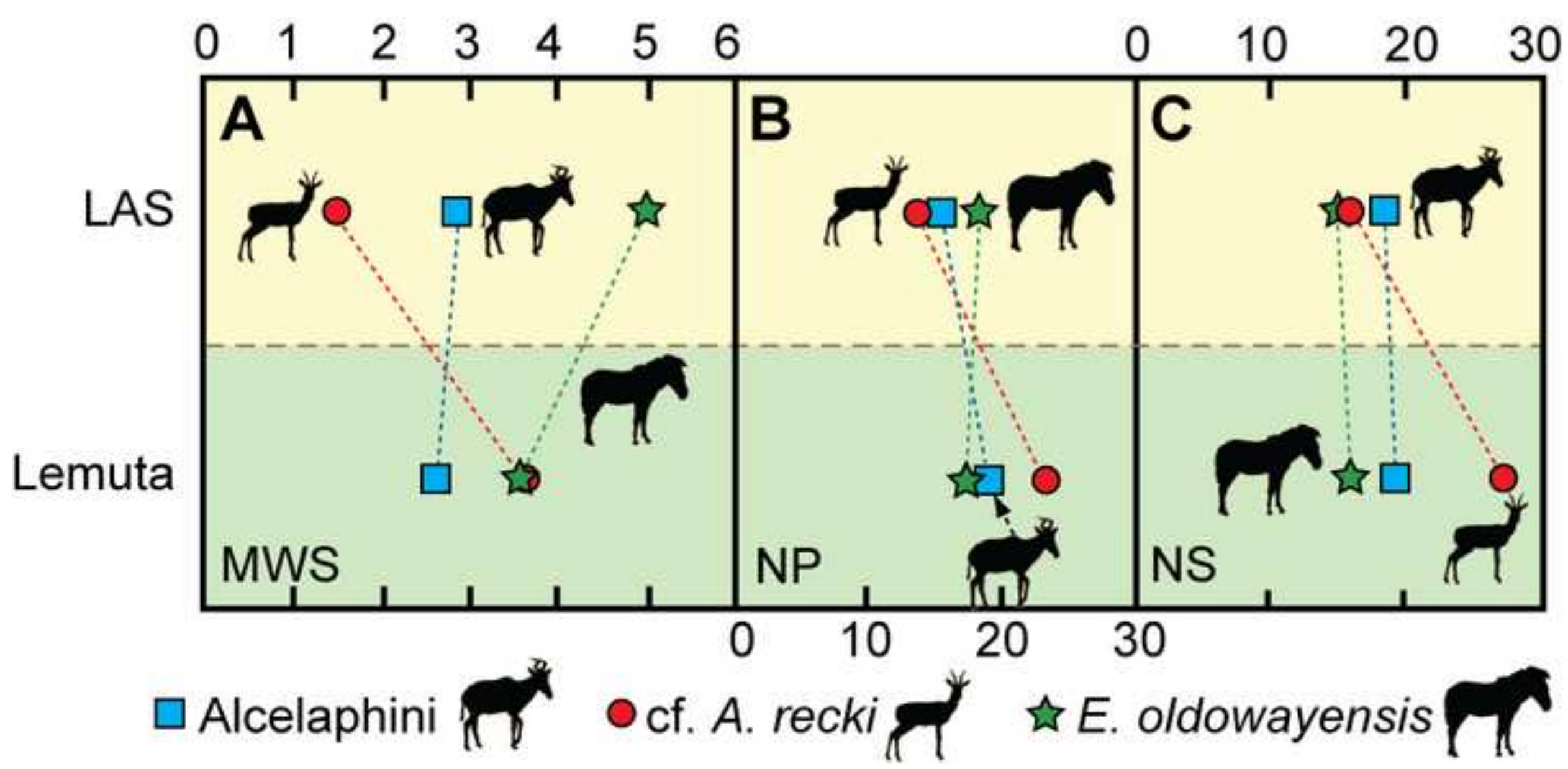




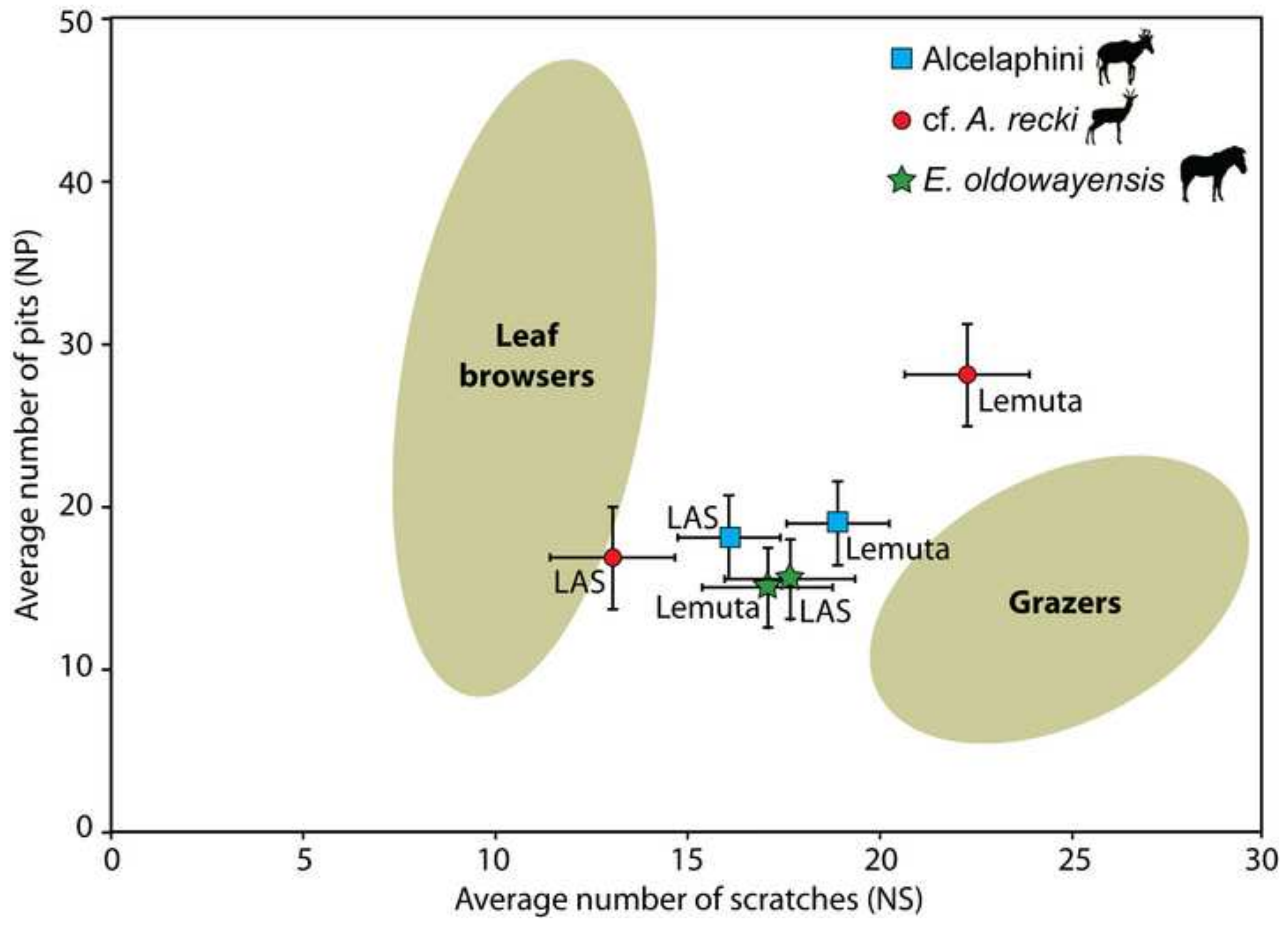



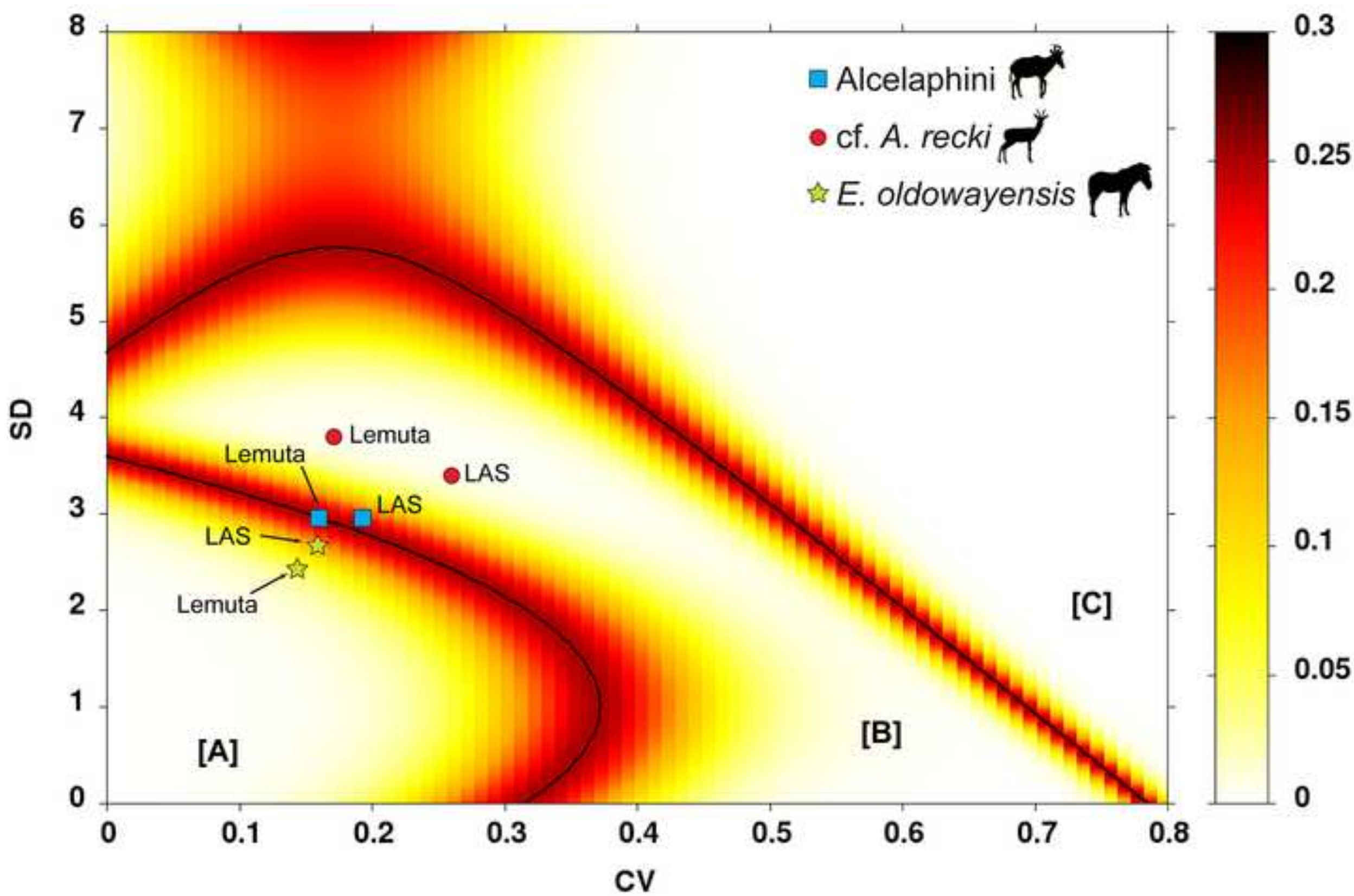
Click here to download high resolution image

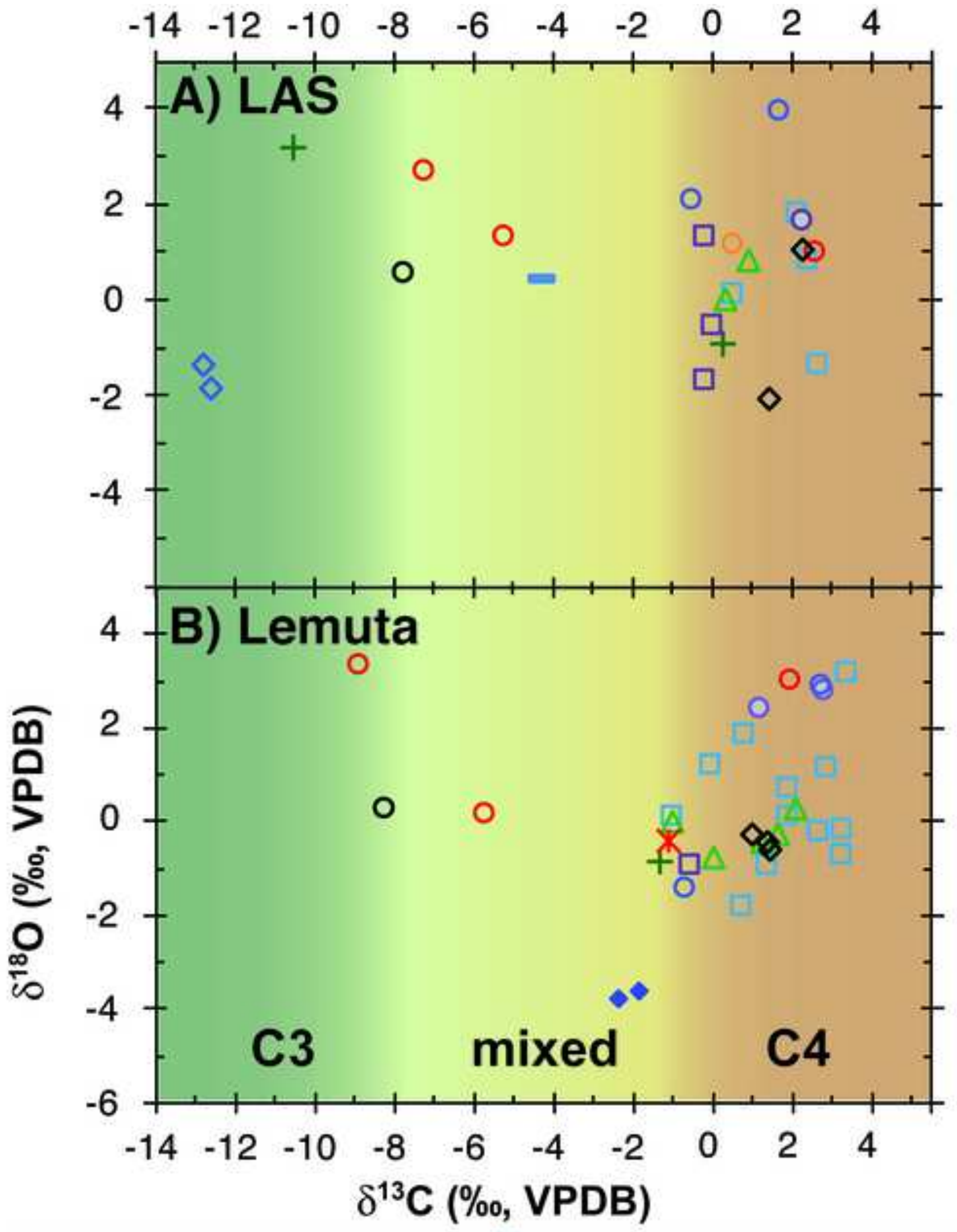

\begin{tabular}{|llll|}
\hline Alcelaphini & $\circ$ Reduncini & $\circ$ Bovini & $\circ$ Hippotragini \\
$\circ$ Antilopini & $\circ$ Tragelaphini & $\diamond$ Deinotheriidae & $\triangle$ Equidae \\
+ Giraffidae & $\diamond$ Rhinocerotidae & $\square$ Suidae & $\times$ Cercopithecidae \\
- Hyaenidae & $\diamond$ Hippopotamidae & & \\
\hline
\end{tabular}




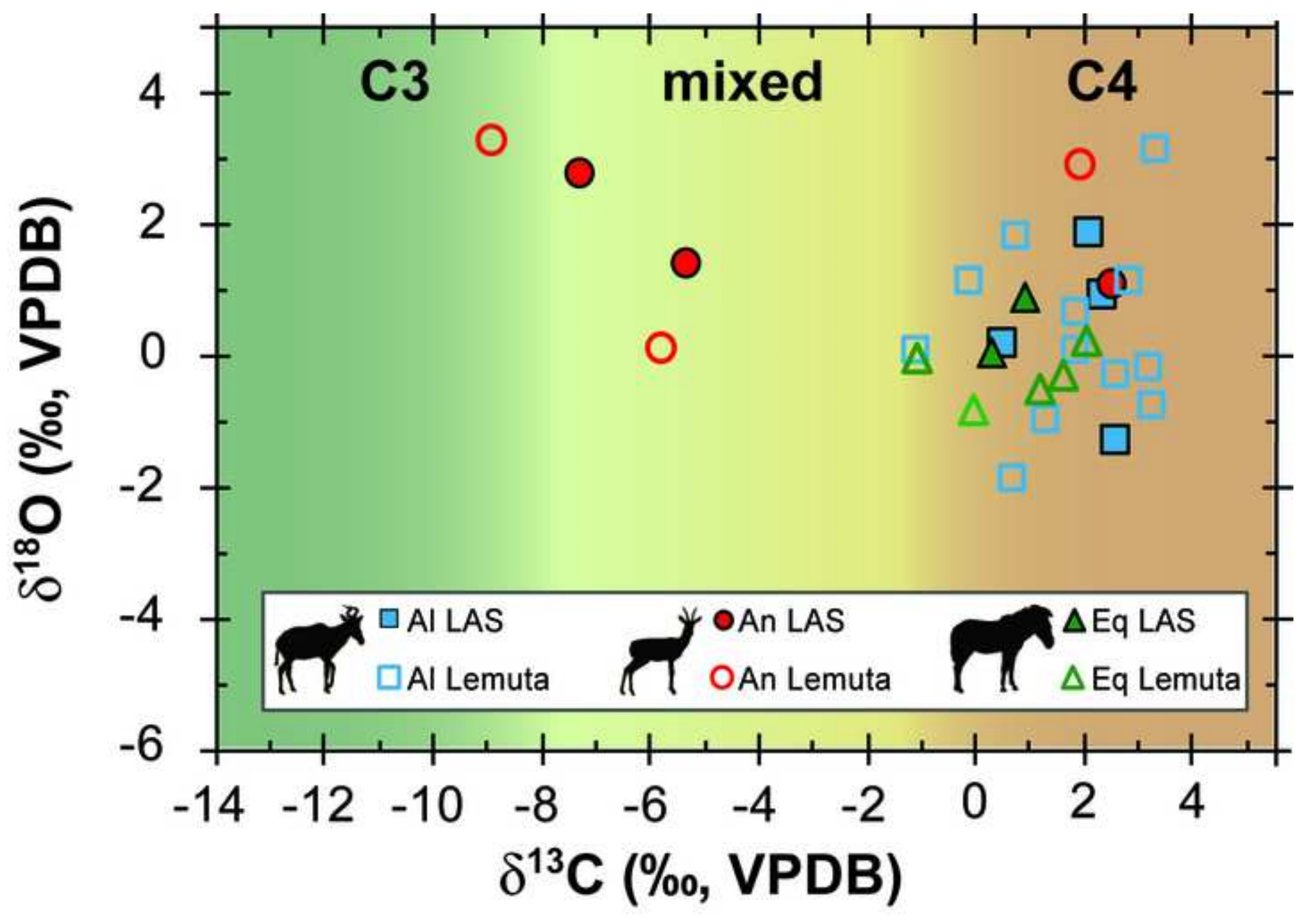



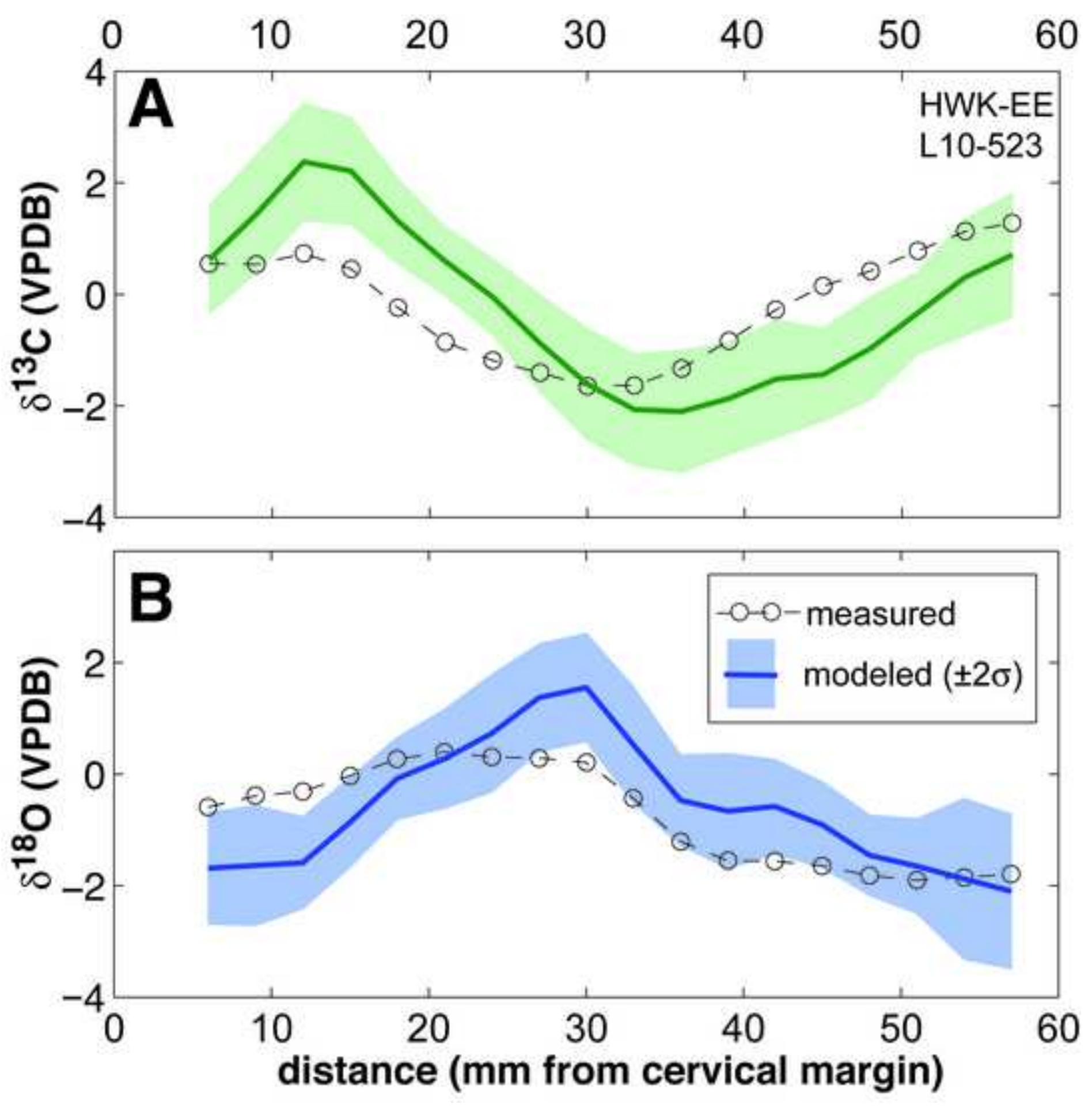
Supplementary Material

Click here to download Supplementary Material: SI Tables 1, 2, 3.xIsx

\begin{abstract}
(n)
\end{abstract} ton

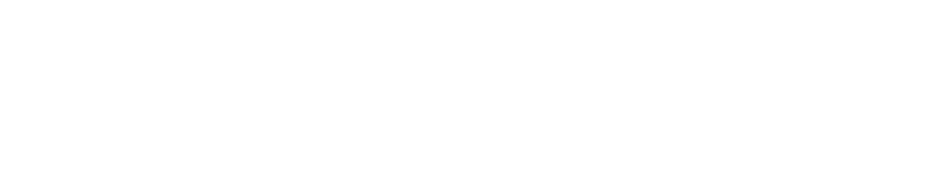

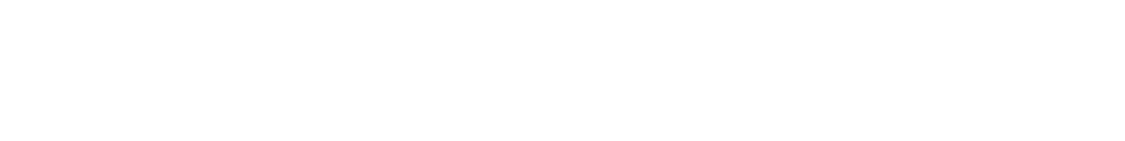
(1) (1) (1) (1) (1) (1) (1) . . . . . . . 